\title{
Traditional herbal medicine in Far-west Nepal: a pharmacological appraisal
}

\author{
Ripu M Kunwar ${ }^{1 *}$, Keshab P Shrestha², Rainer W Bussmann ${ }^{3}$
}

\begin{abstract}
Background: Plant species have long been used as principal ingredients of traditional medicine in far-west Nepal. The medicinal plants with ethnomedicinal values are currently being screened for their therapeutic potential but their data and information are inadequately compared and analyzed with the Ayurveda and the phytochemical findings.

Methods: The present study evaluated ethnomedicinal plants and their uses following literature review, comparison, field observations, and analysis. Comparison was made against earlier standard literature of medicinal plants and ethnomedicine of the same area, the common uses of the Ayurveda and the latest common phytochemical findings. The field study for primary data collection was carried out from 2006-2008.

Results: The herbal medicine in far-west Nepal is the basis of treatment of most illness through traditional knowledge. The medicine is made available via ancient, natural health care practices such as tribal lore, home herbal remedy, and the Baidhya, Ayurveda and Amchi systems. The traditional herbal medicine has not only survived but also thrived in the trans-cultural environment with its intermixture of ethnic traditions and beliefs. The present assessment showed that traditional herbal medicine has flourished in rural areas where modern medicine is parsimoniously accessed because of the high cost and long travel time to health center. Of the 48 Nepalese medicinal plants assessed in the present communication, about half of the species showed affinity with the common uses of the Ayurveda, earlier studies and the latest phytochemical findings. The folk uses of Acacia catechu for cold and cough, Aconitum spicatum as an analgesic, Aesculus indica for joint pain, Andrographis paniculata for fever, Anisomeles indica for urinary affections, Azadirachta indica for fever, Euphorbia hirta for asthma, Taxus wallichiana for tumor control, and Tinospora sinensis for diabetes are consistent with the latest pharmacological findings, common Ayurvedic and earlier uses.

Conclusions: Although traditional herbal medicine is only a primary means of health care in far-west Nepal, the medicine has been pursued indigenously with complementing pharmacology and the Ayurveda. Therefore, further pharmacological evaluation of traditional herbal medicine deserves more attention.
\end{abstract}

\section{Background}

Current estimates suggest that, in many developing countries, about two thirds of the population relies heavily on traditional practitioners and medicinal plants to meet primary health care needs [1]. Although modern medicine may be available in these countries, traditional herbal medicine is often been used for historical, cultural, and ecological reasons, in particular this is due to continued availability [2], better compatibility [3] and high acceptance [4]. Traditional herbal medicine

\footnotetext{
* Correspondence: ripukunwar@gmail.com

'Ethnobotanical Society of Nepal, GPO Box 5220, Kathmandu, Nepal

Full list of author information is available at the end of the article
}

possesses greater significance in Nepal Himalaya hence interest in herbal medicine has gradually increased in recent years [5]. As a result, the medicine all over the world is nowadays revalued by extensive researches on base materials plant species and their therapeutic principles, however to date only about five percent of the total plant species have been thoroughly investigated [6-8] to ascertain safety and efficacy of traditional medicines.

Plant species have long been the principal ingredients of traditional medicine [9] and their use dates back to the beginning of human civilization [10]. Herbal medicine has clearly recognizable therapeutic effects [11] as

\section{() Biomed Central}


well as some toxic side-effects [12]. Thus, Nepalese medicinal plants with ethnomedicinal properties are being screened for their active pharmacological effects [13]. The present study therefore evaluated the ethnomedicinal uses of the selected 48 second priority medicinal plants of Baitadi, Dadeldhura and Darchula districts of far-west Nepal and comparatively assessed their uses against earlier standard literature on medicinal plants of the same area, the common uses of the Ayurveda (an ancient traditional system of herbal medicine in the Himalaya) and the latest phytochemical findings.

\section{Materials and methods}

The field study for primary data collection was carried out in the Baitadi, Dadeldhura, and Darchula districts of farwest Nepal from 2006-2008. The districts stretch between $29^{\circ} 01^{\prime}$ and $30^{\circ} 15^{\prime} \mathrm{N}$ latitude, $80^{\circ} 03^{\prime}$ and $81^{\circ} 09^{\prime} \mathrm{E}$ longitude and $357 \mathrm{~m}-7132 \mathrm{~m}$ altitude. The study sites were Anarkholi, Dasharathchand, Jhulaghat, Khodpe, Kulau, Pancheswor, Patan, Salena, and Sera (Baitadi); Brikham, Jakh, Jogbudha, Patram, and Rupal (Dadeldhura), and Dumling,
Gokule, Joljibi, Khalanga, Khar (Figure 1), Lali, and Uku (Darchula). All three districts are situated along the western borders of the country and lie adjacent to India. Due to variations in altitude, topography, and bio-climate within the districts, the diversity of medicinal plants and knowledge of utilization are vast. The subsistence use is profound particularly for home herbal healing $[5,14]$. There are a number of diverse ethnic groups in the area. The largest ethnic group is the Chhetri (more than 50\%), followed by Brahmin (about 20\%), Dalits (about 10\%), Thakuri (7\%), Magar (2\%), and a few other groups. The first two groups are considered privileged and the rest are considered ethnic (Janajati) and disadvantaged (Dalits). Ethnic and disadvantaged groups have easy access opportunities provided by the government.

\section{Field surveys and data collection}

Four field surveys were carried out during different seasons of the year (May, December 2006, February 2007, March-April 2008). Each survey lasted over 20 days in the field. Primary data collection, after establishing oral

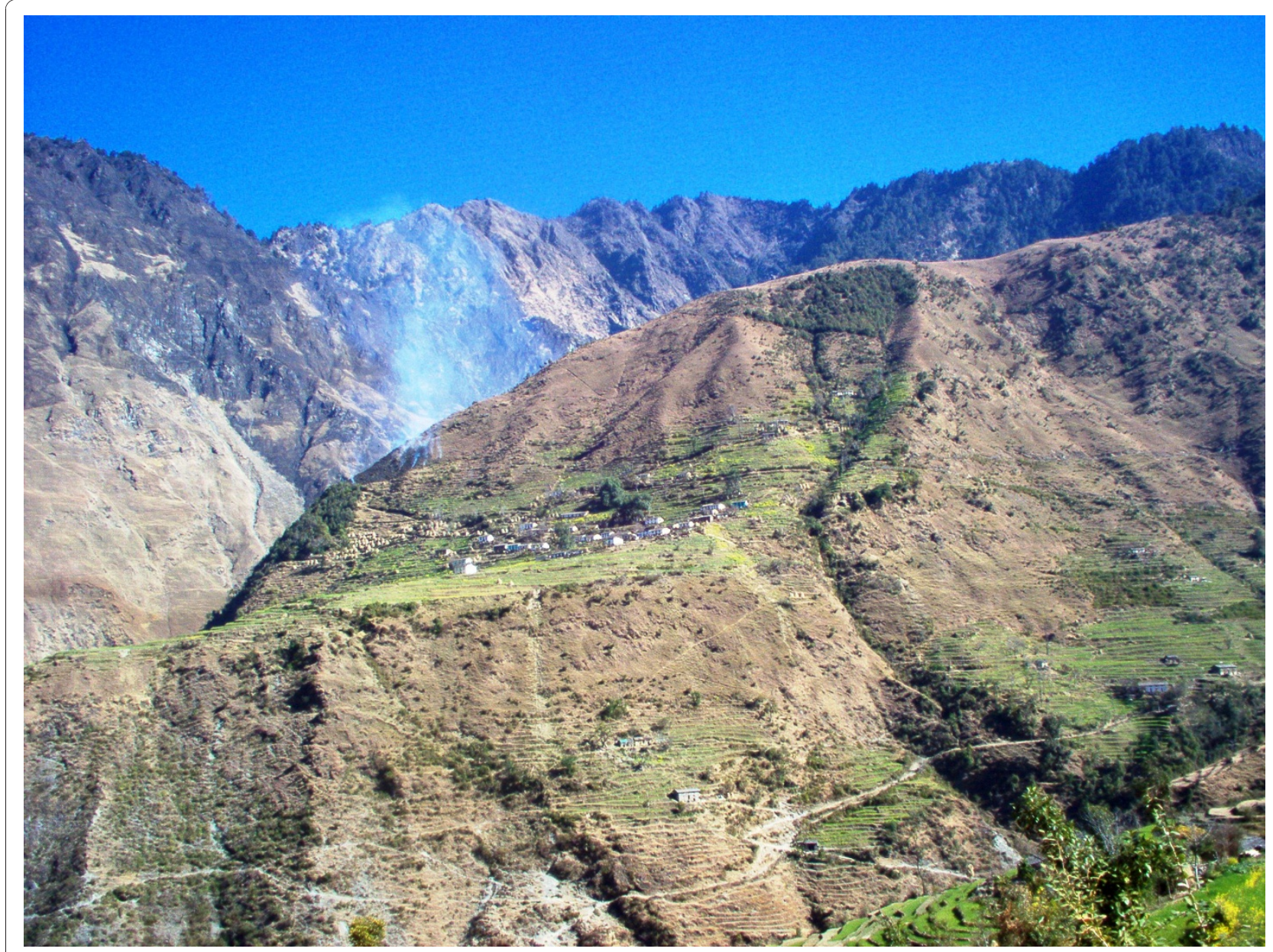

Figure 1 Study site: Khar VDC, Darchula district 
informed consent with the participating communities, consisted of group discussions, informal meetings, schedule surveys, key informant surveys, cross-checking, and field observations. In all surveys, four group discussions and six informal meetings were held; in total 172 individuals were consulted. Informal meetings were held in villages while staying with them. The traditional healers (Baidhyas) and women representing major ethnic groups, castes, and occupations were encouraged to participate. Baidhyas are traditional medicinal practitioners particularly of the western Nepal mid-hills [15] and adjoining areas of India [16]. Women were active participants of the informal meetings. Among the respondents, $3 \%$ were traditional healers, $12 \%$ were ethnic groups, and $21 \%$ were women.

All plant species encountered during field observations were recorded. Medicinal plant species were collected during the day and displayed during evening meetings for discussion. Both the collections and surveys/discussions were facilitated by local assistants, and the information was sought about vernacular dialects, indigenous uses of the species and participants' priority on species. Ranking was followed to categorize the first, second and third priority medicinal plant species. The species enumerated in the present study were the second priority medicinal plants of the local communities with informant consensus factor less than 0.85 . The first priority medicinal plants with quantitative ethnomedicine were already discussed $[14,17]$.

Matching information from at least three respondents (mentions) was counted as a common response for the analysis. The single most common folk use of each species was valued for further discussion. Common species and mono specific genera which were well known by their dialect names were used only for discussion and not managed as voucher specimen for further identification. Voucher specimens were collected, and vernacular names and folk uses were recorded for each specimen. Specimen collection was made following Cunningham [18], and plants were identified to species level. Most of the species were identified in the field using literature $[19,20]$. The remaining unidentified species were identified and housed in Kathmandu at Tribhuvan University Central Herbarium (TUCH), Department of Botany, Tribhuvan University, Nepal.

The observations of the present survey were compared to earlier observations, latest common phytochemical findings and common uses of the Ayurveda. The common uses of the Ayurveda were taken from the following literature [21-27]. Literature [28-33] of Nepal were used as reference for earlier ethnomedicinal information of the same area. Pharmacological information was retrieved from internet sources (available till June, 2010) and relevant journals; most of them were accessed from
USA. About 240 research papers and articles were reviewed for analysis.

\section{Results and Discussion \\ Traditional herbal medicine}

Traditional herbal medicine has been used since ancient time in many parts of the world where access to formal and modern healthcare is limited. Nepal is not exempt and in mid-hills, mountainous and rural areas of the country where access and services are limited, herbal medicine is the basis of treatment of most illness through traditional knowledge. It is estimated that approximately $90 \%$ of the Nepalese people reside in rural areas where access to government health care facilities is lacking [30]. These people rely predominantly on traditional herbal medicine. Traditional medicine is made available via ancient, natural health care practices such as tribal lore, home herbal remedy, and the Baidhya, Ayurveda and Amchi (traditional healing system of Tibet and mountain areas of Nepal) systems. The former one is innate to the tribal group (i.e. Raute in study area) [34]. Home herbal remedy and the Baidhya system are indigenous to far-west Nepal [14,15] and are partly influenced by the Ayurveda [35]. Extant of home herbal remedy in far-west Nepal is also due to relatively homogenous resource users and less encroachment from immigrants. Home herbal remedy and Baidhya system, yet transformations of the Ayurveda, are well established and practiced in the study area. The Amchi system is widely accepted and practiced throughout high altitude areas of Nepal [10] and is important in Darchula district, albeit with some modifications [29].

As communicated by Kunwar et al. [17], the knowledge base for traditional herbal medicine stems from spirituality, customs, livelihood strategies and available nearby resources. Medicinal herbs are main ingredients of traditional herbal medicine, and the traditional herbal medicine is considered as the main lifeline [36], the first choice [37], fewer side-effects, better patience tolerance, relatively less expense, and cultural acceptance and long history of use, in comparison to western medicine. Thus, the traditional herbal medicine has not only survived but also thrived in the trans-cultural environment with its intermixture of ethnic traditions and beliefs. Most of the time, this knowledge is passed on orally and therefore is endangered. Particularly the Amchi knowledge is passed down through dedicated apprenticeships under the tutelage of senior Amchi [38]. Although traditional herbal medicine is effective in treatment of various ailments with considering ritual and socio-cultural customs [39], very often the medicine is used indigenously with indifference to the scientific knowledge and their possible side effects were overlooked. The dearth of reports of adverse effects and interactions probably 
reflect a combination of under-reporting and the benign nature of most herbs used [40]. Therefore, the traditional herbal medicine deserves a great scope of research in the light of modern science.

The present assessment showed that traditional herbal medicine has flourished in rural areas where modern medicine is parsimoniously accessed as a result of the high cost and long travel time to health center. Moreover inadequate modern medical resources/facilities and government subsidies also made traditional herbal medicine pertinent in Nepal. It is estimated that there is one physician for every 20,000 people whereas there is more than one healer for every 100 people in Nepal $[41,42]$. Herbal medicine prescribed by healers is either preparation based on single plant part or a combination of several plant parts. However, we dealt only the primary one for further discussion in the present study. Many of the plants most often used in study area to treat ailments are also commonly used all over Nepal. Particularly the ethnic groups and scheduled caste are the major stakeholders of the traditional herbal medicine [43], so, traditional medicine is still the mainstay of health care in the rural areas of Nepal where the majorities of the denizens are from ethnic groups and scheduled castes.

\section{Medicinal plants and their uses}

Of the 48 species from 46 genera and 40 families (Table 1) discussed in the present study, indigenous uses of about $70 \%$ species resembled to the earlier ethnomedicinal reports. The indigenous uses of about $50 \%$ species had affinity to the Ayurveda, and about $40 \%$ species were found to have efficacy in pharmacology. Fabaceae, Moraceae and Rosaceae were represented by the greatest number of species (3 each), followed by Euphorbiaceae and Lamiaceae (2 each) for herbal medicine in study area. A total of 30 ailments were reported in the present study, and among these inflammation, cuts \& wounds, diarrhea \& dysentery and fever were considered as common, and the maximum number of medicinal plant species were used against, six species to each category and four for the latter. Similar observation of maximum number of species used for fever and cuts \& wounds was reported by Manandhar [34]. The plant parts used for herbal remedies were bark, flower, fruit, leaf, milk/latex, root/rhizome, seed, shoot, wood, and the whole plant. Plant parts root/rhizome, leaf, and fruits, etc. were most frequently utilized.

\section{Pharmacology}

The results obtained support prior observations, pharmacology and Ayurvedic uses concerning the following species: the crude extracts of Acacia catechu for cold and cough, Aconitum spicatum as analgesic, Aesculus indica for joint pain, Andrographis paniculata for fever, Anisomeles indica for urinary affections, Azadirachta indica for fever, Euphorbia hirta for asthma, Taxus wallichiana for tumor control, and Tinospora sinensis for diabetes. This probably explains the use of these plants by indigenous people against a number of infections as transcend from transcultural environment with following home herbal remedy, Ayurveda and Baidhya systems. It is known that the families Rutaceae and Meliaceae are among the richest and most diverse sources of secondary metabolites among the angiosperms [44], and the species of Meliaceae are known to have intense antimalarial characters due to highly oxygenated terpenoids [45]. Use of leaves of Azadirachta indica (Meliaceae) as antipyretic is widely used in study area (Table 1) and throughout Nepal [46] was substantiated by the nimbidin flavonoids $[47,48]$. Oleic acid and gedunin of $A$. indica are also reported to be an in vitro antimalarial [49-51]. Other species contributed as antipyretic in home herbal remedy in study area were Andrographis paniculata (Acanthaceae), Aconitum spicatum (Ranunculaceae) and Osmanthes fragrans (Oleaceae).

Andrographolide and neoandrographolide from Andrographis paniculata own anti-inflammatory activity $[52,53]$. Its diterpene exhibits antioxidant and hepatoprotective properties [54-57]. Immunostimulant [58], antibacterial [59], analgesic [60] and antiprotozoal [61] characteristics of $A$. paniculata extract have also been demonstrated. These values probably explain the use of A. paniculata by the indigenous people against a number of infections and fever. Crude root extract of Podophyllum hexandrum (Berberidaceae) was used as hepatoprotective, despite the hepatotoxic character reported due to its lignans [62]. Podophyllotoxin has manifested antimitotic activity and capability of inhibiting DNA, RNA and protein synthesis [63]. There were seven species in study area exhibiting hepato-protective effects. Among them, six were pharmacology based and three were folkloric. Plant extracts of $P$. hexandrum and Andrographis paniculata showed hepato-protective characters consistent with the folk use and pharmacology.

Alkaloids are most common in flowering plants, especially in Fabaceae, Ranunculaceae and Solanaceae [64]. Some alkaloids (aconitine, anisodamine, berberine, charantine, leurosine) show antidiabetic effects [65]. Berberine of Tinospora sinensis (Menispermaceae) is antidiabetic [66-68], but higher doses may be antagonistic [69], which strongly support the folkloric use of the plant extract. According to Marles and Farnsworth [70], there are about 1,000 species of plants that can act as antidiabetic and approximately $80 \%$ of these are used in folk herbal medicine. Antidiabetic reports of Azadirachta indica, Carum carvi, Tinospora sinensis and Vitex negundo stated in the present communication were 
Table 1 Major uses of the medicinal plants, their chemical constituents, and latest common pharmacological findings (species are in order of references)

\begin{tabular}{|c|c|c|c|c|c|c|}
\hline $\mathrm{SN}$ & $\begin{array}{l}\text { Scientific name, } \\
\text { local name, family } \\
\text { and voucher code }\end{array}$ & $\begin{array}{l}\text { Folk use found } \\
\text { in present } \\
\text { survey }\end{array}$ & $\begin{array}{l}\text { Major folk uses in } \\
\text { previous studies }\end{array}$ & $\begin{array}{l}\text { Major uses in the } \\
\text { Ayurveda }\end{array}$ & $\begin{array}{l}\text { Selected major chemical } \\
\text { constituents }\end{array}$ & $\begin{array}{l}\text { Latest common } \\
\text { pharmacological } \\
\text { findings }\end{array}$ \\
\hline 1. & $\begin{array}{l}\text { - } \otimes \text { Lobelia pyramidalis } \\
\text { Wall. Campanulaceae } \\
\text { Lobelia (E), Aklebir (N), } \\
\text { Eklebir (S), 569/00. } \\
\text { Syn. L. nicotianaefolia } \\
\text { Roth }\end{array}$ & $\begin{array}{l}\text { Juice of leaves } \\
\text { and flowers is } \\
\text { rubbed on } \\
\text { body parts } \\
\text { during body } \\
\text { ache. }\end{array}$ & $\begin{array}{l}\text { Leaves and } \\
\text { inflorescence are } \\
\text { antispasmodic [30] and } \\
\text { used for asthma, } \\
\text { bronchitis and fever } \\
\text { [31]. }\end{array}$ & $\begin{array}{l}\text { Leaves and flowers } \\
\text { are antispasmodic } \\
\text { and they are used as } \\
\text { an expectorant. Plant } \\
\text { is used for sciatia } \\
\text { and back pain [21]. }\end{array}$ & Lobeline, radicamine. & $\begin{array}{l}\text { Lobeline may cause } \\
\text { nausea, vomiting and } \\
\text { diarrhea [38]. }\end{array}$ \\
\hline 2. & $\begin{array}{l}\text { P } \otimes \text { Cannabis sativa L. } \\
\text { Cannabaceae Hemp } \\
(\text { E), Ganja (N), Bhang } \\
\text { (S). } \\
\text { Syn. C. indica Lam. }\end{array}$ & $\begin{array}{l}\text { Leaf juice is } \\
\text { applied to } \\
\text { control } \\
\text { bleeding. }\end{array}$ & $\begin{array}{l}\text { Leaf juice is useful for } \\
\text { healing wounds, } \\
\text { control bleeding and } \\
\text { stomachache [32]. }\end{array}$ & $\begin{array}{l}\text { Plant is efficacious } \\
\text { for diarrhea. It is also } \\
\text { used as } \\
\text { antispasmodic [21] } \\
\text { and sedative [25]. }\end{array}$ & $\begin{array}{l}\text { Cannabigerol, cannabidiol, } \\
\text { friedelin, lectins [32]. }\end{array}$ & $\begin{array}{l}\text { Leaves are used as } \\
\text { snuff for smoking and } \\
\text { are given internally to } \\
\text { relieve pain and } \\
\text { swelling [27]. Lectins } \\
\text { possess haema- } \\
\text { gluttinating properties } \\
\text { [38]. }\end{array}$ \\
\hline 3. & $\begin{array}{l}\text { QScutellaria discolor } \\
\text { Colebr. Lamiaceae } \\
\text { Ratpatya (L), Dampate } \\
\text { (N) KU } 07263 \text {. } \\
\text { Syn. S. indica Blume }\end{array}$ & $\begin{array}{l}\text { Whole plant } \\
\text { and leaf paste is } \\
\text { useful for cuts } \\
\text { and wounds. }\end{array}$ & $\begin{array}{l}\text { Plant juice is useful for } \\
\text { headache and fever } \\
\text { [28] and wounds } \\
\text { healing [30]. }\end{array}$ & $\begin{array}{l}\text { Plant juice is used } \\
\text { for rheumatism } \\
\text { [147]. }\end{array}$ & Wogonin & $\begin{array}{l}\text { Root juice is given in } \\
\text { indigestion and } \\
\text { wogonin exerts } \\
\text { anxiolytic effects [135]. } \\
\text { Plant and root extract } \\
\text { is used for rheumatism } \\
\text { [136]. }\end{array}$ \\
\hline 4. & $\begin{array}{l}\text { QFicus palmata } \\
\text { Forssk. Moraceae } \\
\text { Bedu (N). } \\
\text { Syn. F. virgata Wall. }\end{array}$ & $\begin{array}{l}\text { Plant milk is } \\
\text { useful for taking } \\
\text { out the thorns } \\
\text { from wounds. }\end{array}$ & $\begin{array}{l}\text { Plant latex is used to } \\
\text { expel the spines [30]. } \\
\text { Fruits are used for } \\
\text { constipation, lungs and } \\
\text { bladders diseases [33]. }\end{array}$ & $\begin{array}{l}\text { Fruits are taken for } \\
\text { lungs disorders [147]. }\end{array}$ & Friedelin, tannins. & $\begin{array}{l}\text { Fruits act as demulcent } \\
\text { and laxative and are } \\
\text { useful for lungs, spleen } \\
\text { and bladders [136]. }\end{array}$ \\
\hline 5. & $\begin{array}{l}\text { PGrewia disperma } \\
\text { Rottb. Tiliaceae } \\
\text { Viywal (L), Syalpuchre } \\
\text { (N). } \\
\text { Syn. G. serrulata DC. }\end{array}$ & $\begin{array}{l}\text { Root juice is } \\
\text { taken as } \\
\text { expectorant. } \\
\text { Wood paste is } \\
\text { applied for skin } \\
\text { diseases (no } \\
\text { other } \\
\text { information } \\
\text { given). }\end{array}$ & $\begin{array}{l}\text { Root juice is taken } \\
\text { during cough and } \\
\text { cold. Bark paste is } \\
\text { expectorant and used } \\
\text { for boils [33]. }\end{array}$ & $\begin{array}{l}\text { Root juice is used for } \\
\text { controlling bleeding } \\
\text { and bronchitis [147]. }\end{array}$ & - & $\begin{array}{l}\text { Plant is applied in } \\
\text { bleedings and } \\
\text { bronchitis. Fruits are } \\
\text { valued as cardiotonic } \\
\text { [136]. }\end{array}$ \\
\hline 6. & $\begin{array}{l}\text { QPodophyllum } \\
\text { hexandrum Royle } \\
\text { Berberidaceae } \\
\text { Podophyllum, May } \\
\text { apple (E), Laghupatra } \\
\text { (N), Hatkaudo (L), } \\
\text { Hansapadi, } \\
\text { Laghupatra (S), 583/ } \\
\text { 00. } \\
\text { Syn. P. emodi Wall. ex } \\
\text { Hook. f. \& Thomson }\end{array}$ & $\begin{array}{l}\text { Root juice is } \\
\text { taken for liver } \\
\text { complaints (no } \\
\text { other } \\
\text { information } \\
\text { given). }\end{array}$ & $\begin{array}{l}\text { Plant is hepato- } \\
\text { stimulant and } \\
\text { purgative }[15,31] \text {. Root } \\
\text { paste is applied on } \\
\text { ulcer, cuts and wounds } \\
\text { [32]. }\end{array}$ & $\begin{array}{l}\text { Root extract is } \\
\text { purgative [147]. }\end{array}$ & $\begin{array}{l}\text { Aryltetralin, astragalin, } \\
\text { lignan, picropodophyllin, } \\
\text { podophyllotoxin, quercetin } \\
\text { [27]. }\end{array}$ & $\begin{array}{l}\text { Plant lignan is } \\
\text { hepatotoxic [62], } \\
\text { aryltetralin is antifungal } \\
\text { [148], and } \\
\text { podophyllotoxin is } \\
\text { antitumour. Aqueous } \\
\text { extract of plant has } \\
\text { antitumor effects [149]. }\end{array}$ \\
\hline 7. & $\begin{array}{l}\text { - } \otimes \text { Potentilla fulgens } \\
\text { Wall. Ex Hook. } \\
\text { Rosaceae Himalayan } \\
\text { Cinquefoil (E), Phosre } \\
\text { (L), Bajradanti (N), } \\
\text { Kanthamun (S), 93/00. } \\
\text { Syn. P. siemersiana } \\
\text { Lehm. }\end{array}$ & $\begin{array}{l}\text { Dried roots are } \\
\text { eaten as } \\
\text { dentifrice. }\end{array}$ & $\begin{array}{l}\text { Root used as tooth } \\
\text { powder for toothache } \\
{[30,31] \text {. }}\end{array}$ & $\begin{array}{l}\text { Root powder is used } \\
\text { for toothache [25]. }\end{array}$ & $\begin{array}{l}\text { Carotene, coumarins, } \\
\text { flavonoids, polyphenols, } \\
\text { sterols [25]. }\end{array}$ & $\begin{array}{l}\text { Aqueous extract of the } \\
\text { plant reduced } \\
\text { germination of food } \\
\text { crops [150]. }\end{array}$ \\
\hline
\end{tabular}


Table 1: Major uses of the medicinal plants, their chemical constituents, and latest common pharmacological findings (species are in order of references) (Continued)

\begin{tabular}{lll}
\hline 8. $\otimes$ Carum carvi L. & Fruits are & Plant fruit juice is \\
Apiaceae Caraway & applied against & useful for muscular \\
(E), Jangali jira (L), & swelling of & swellings [30]. Raw \\
Kalo jira (N). & breast and & fruits are stomachic \\
Syn. Apium carvi L. & testicles. & and carminative [31].
\end{tabular}

\author{
Plant seeds are \\ useful in uterinal \\ complaints [22], and \\ used as \\ antidysenteric, \\ astringent, \\ anthelminthic and \\ carminative [151].
}

Camphene, carvone,
caryophyllene, limonene,
myrcene, pinene, sabinene,
scopoletin, umbelliferone
[100].

Fruits are good for painful swelling [152]. Carvone is anthelmintic [153] and antioxidative [154]. Essential oil is antibacterial [155] and antitumeric [156]. Aquous fruit extract is used against hypertension, gonorrhoea [157] and diabetes [158].

\begin{tabular}{|c|c|c|c|c|c|c|}
\hline 9. & $\begin{array}{l}\text { P• } \otimes \text { Aconitum } \\
\text { spicatum (Bruhl) Stapf. } \\
\text { Ranunculaceae } \\
\text { Nepalese Aconite (E), } \\
\text { Bikh (N), Bish (S), KU } \\
07233 \text {. } \\
\text { Syn. A. ferox var. } \\
\text { spicata Bruhl }\end{array}$ & $\begin{array}{l}\text { Root juice is } \\
\text { antipyretic and } \\
\text { analgesic. }\end{array}$ & $\begin{array}{l}\text { Tubers are used after } \\
\text { detoxification [31] as } \\
\text { antipyretic and } \\
\text { analgesic [32]. }\end{array}$ & $\begin{array}{l}\text { Plant tuber is } \\
\text { antipyretic and } \\
\text { analgesic [25]. Plant } \\
\text { root is used for } \\
\text { tonsillitis, sore throat, } \\
\text { gastritis, and debility } \\
\text { [152]. }\end{array}$ & $\begin{array}{l}\text { Bikhaconitine, caffeic acid, } \\
\text { diterpenoids, lupenoic acid, } \\
\text { pseudaconitine. }\end{array}$ & $\begin{array}{l}\text { Caffeic acid of } \\
\text { Aconitum species is } \\
\text { antioxidative and anti- } \\
\text { inflammatory [138]. }\end{array}$ \\
\hline 10. & $\begin{array}{l}\text { Y. } \otimes \text { Taxus wallichiana } \\
\text { (Zucc.) Pilger } \\
\text { Taxaceae Himalayan } \\
\text { Yew (E), Kandeloto (L), } \\
\text { Lothsalla (N), } \\
\text { Madhuparni (S), 99/00. } \\
\text { Syn. T. baccata auct. } \\
\text { non. }\end{array}$ & $\begin{array}{l}\text { Leaf juice is } \\
\text { used for cancer } \\
\text { and bronchitis. }\end{array}$ & $\begin{array}{l}\text { Bark and leaf juice is } \\
\text { useful for asthma, } \\
\text { bronchitis and cancer } \\
{[30,32] \text {. }}\end{array}$ & $\begin{array}{l}\text { Dried leaves are } \\
\text { considered to be } \\
\text { useful for asthma, } \\
\text { bronchitis, hiccough, } \\
\text { epilepsy, diarrhea } \\
\text { and headache [151]. }\end{array}$ & $\begin{array}{l}\text { Abeotaxane, baccatin, } \\
\text { cephalomannin, docetaxol, } \\
\text { paclitaxel, taxol [159]. }\end{array}$ & $\begin{array}{l}\text { Fractions of extract of } \\
\text { leaves inhibited } \\
\text { pregnancy in } 60 \% \\
\text { female rats [22]. It } \\
\text { cures vitiation of blood } \\
\text { [100] and inhibits } \\
\text { tumor growth [101]. }\end{array}$ \\
\hline 11. & $\begin{array}{l}\text { P. } \otimes \text { Acacia catechu (L. } \\
\text { f.) Willd. Fabaceae } \\
\text { Cutch tree (E), Khair } \\
\text { (N), Khadirah (S). } \\
\text { Syn. A. catechoides } \\
\text { (Roxb.) }\end{array}$ & $\begin{array}{l}\text { Wood is used } \\
\text { as local tea for } \\
\text { cough and cold. }\end{array}$ & $\begin{array}{l}\text { Wood decoction is } \\
\text { applied on nosebleeds, } \\
\text { skin eruptions and } \\
\text { toothache [30] and for } \\
\text { cough and bodyache } \\
\text { [32]. }\end{array}$ & $\begin{array}{l}\text { Plant decoction is } \\
\text { used for skin } \\
\text { diseases and mouth } \\
\text { and mucous defects } \\
\text { [21]. Wood is useful } \\
\text { for cough and } \\
\text { diarrhea [25]. }\end{array}$ & $\begin{array}{l}\text { Acacatechin, afzelchin, } \\
\text { catechuic acid, } \\
\text { catechutannic acid, } \\
\text { cyanidanol, dimeric } \\
\text { procyanidine, epicatechin, } \\
\text { isorhamnetin, phlebotanin, } \\
\text { quercetin, taxifolin, } \\
\text { tryptamine, vernolic acid } \\
\text { [160]. }\end{array}$ & $\begin{array}{l}\text { Cyanidanol, an active } \\
\text { ingrediant of Acacia } \\
\text { catechu, is claimed to } \\
\text { be effective for } \\
\text { treating liver diseases } \\
\text { [95]. Catechu has } \\
\text { hypoglycaemic [161], } \\
\text { antipyretic [162] and } \\
\text { digestive properties } \\
\text { [163]. Taxifolin has } \\
\text { antioxidant and anti- } \\
\text { inflammatory activities } \\
\text { [164]. Catechuic acid is } \\
\text { valued for } \\
\text { expectoration for chest } \\
\text { infection [165]. }\end{array}$ \\
\hline 12. & $\begin{array}{l}\text { QEngelhardia spicata } \\
\text { Leschen. ex Blume } \\
\text { Juglandaceae } \\
\text { Mahuwa (N). } \\
\text { Syn. E. colebrookeana } \\
\text { Lindl. ex Wall. }\end{array}$ & $\begin{array}{l}\text { Flower juice is } \\
\text { drunk for } \\
\text { abdominal pain. }\end{array}$ & $\begin{array}{l}\text { Flower juice is useful } \\
\text { for abdominal pain [5], } \\
\text { cough and cold [166]. }\end{array}$ & $\begin{array}{l}\text { Bark is used as } \\
\text { piscidal [147]. }\end{array}$ & $\begin{array}{l}\text { Engelhardtione, oleanolic } \\
\text { acid. }\end{array}$ & $\begin{array}{l}\text { Engelhardtione } \\
\text { possesses } \\
\text { antituberculer activities } \\
\text { [167]. }\end{array}$ \\
\hline 13. & $\begin{array}{l}\text {-Spondias pinnata (L.f.) } \\
\text { Kurtz Anacardiaceae } \\
\text { Bile tree, Wild mango } \\
\text { (E), Amaro (L), } \\
\text { Pitavraksha (S). } \\
\text { Syn. S. mangifera } \\
\text { Willd. }\end{array}$ & $\begin{array}{l}\text { Plant latex is } \\
\text { applied for } \\
\text { wounds and } \\
\text { cuts. }\end{array}$ & $\begin{array}{l}\text { Plant juice is useful for } \\
\text { dysentery and } \\
\text { rheumatism [30] plant } \\
\text { latex is used for bilious } \\
\text { dyspepsia [33]. }\end{array}$ & $\begin{array}{l}\text { Latex is demulcent } \\
{[27] .}\end{array}$ & $\begin{array}{l}\text { Alanine, amyrin, cystine, } \\
\text { lignoceric acid, oleanolic } \\
\text { acid, serine }[27,100] \text {. }\end{array}$ & $\begin{array}{l}\text { Flavonoids of the plant } \\
\text { have been known to } \\
\text { inhibit intestinal } \\
\text { motility and } \\
\text { hydroelectrolytic } \\
\text { secretion, which are } \\
\text { known to be altered } \\
\text { for diarrhoeal } \\
\text { conditions [168]. }\end{array}$ \\
\hline
\end{tabular}


Table 1: Major uses of the medicinal plants, their chemical constituents, and latest common pharmacological findings (species are in order of references) (Continued)

\begin{tabular}{|c|c|c|c|c|c|c|}
\hline 14. & $\begin{array}{l}\otimes \text { Schleichera oleosa } \\
\text { (Lour.) Oken } \\
\text { Sapindaceae } \\
\text { Macassar tree, Honey } \\
\text { tree, Lac host tree (E), } \\
\text { Kusum (N). } \\
\text { Syn. S. trijuga Willd }\end{array}$ & $\begin{array}{l}\text { Fruits are eaten } \\
\text { as an } \\
\text { anthelmintic. }\end{array}$ & $\begin{array}{l}\text { Fruits are used for heat } \\
\text { stroke, and valued as } \\
\text { appetite stimulant [30], } \\
\text { anthelmintic and tonic } \\
\text { [33]. }\end{array}$ & $\begin{array}{l}\text { Seed oil is used for } \\
\text { skin diseases [27]. }\end{array}$ & $\begin{array}{l}\text { Behemin, campesterol, } \\
\text { gadoleic acid, oleic acid, } \\
\text { oxalic acid, palmitic acid, } \\
\text { stearic acid, tartaric acid [27]. }\end{array}$ & $\begin{array}{l}\text { Fruit juice stimulates } \\
\text { hair growth [169]. }\end{array}$ \\
\hline 15. & $\begin{array}{l}\text { Rhododendron } \\
\text { campanulatum D.Don } \\
\text { Ericaceae Chimal (N) } \\
89 / 00 \text {. } \\
\text { Syn. R. wallichii Hook.f. }\end{array}$ & $\begin{array}{l}\text { Flowers are } \\
\text { used in body } \\
\text { ache and throat } \\
\text { pain. Seeds aid } \\
\text { digestion. }\end{array}$ & $\begin{array}{l}\text { Flowers are useful for } \\
\text { skin diseases [33]. }\end{array}$ & $\begin{array}{l}\text { Leaf extract is used } \\
\text { for rheumatism and } \\
\text { syphilis [147]. }\end{array}$ & $\begin{array}{l}\text { Amyrin, andromedotoxin, } \\
\text { campanulin, chlorogenic } \\
\text { acid, epifriedelinol, gallic } \\
\text { acid, phenols, quercetin, } \\
\text { ursolic acid }[170,171] \text {. }\end{array}$ & $\begin{array}{l}\text { Plant andromedotoxin } \\
\text { is poisonous to the } \\
\text { livestock [136]. Good } \\
\text { amount of phenols } \\
\text { and ursolic acid in the } \\
\text { plant help to reduce } \\
\text { risk of cardiovascular } \\
\text { diseases }[129,171] \text { and } \\
\text { cancer }[172,173] \text {. }\end{array}$ \\
\hline 16. & $\begin{array}{l}\text { Boehmeria platyplylla } \\
\text { D.Don Urticaceae } \\
\text { Chinese grass (E), } \\
\text { Kamle (L), Gargalo (N). } \\
\text { Syn. B. macrostachya } \\
\text { Wedd. }\end{array}$ & $\begin{array}{l}\text { Root paste is } \\
\text { applied on } \\
\text { control } \\
\text { bleeding. }\end{array}$ & $\begin{array}{l}\text { Root juice is given for } \\
\text { stomachache [28] and } \\
\text { dysentery [30]. }\end{array}$ & $\begin{array}{l}\text { Plant juice is } \\
\text { poisonous to fish } \\
\text { [147]. }\end{array}$ & $\begin{array}{l}\text { Acetophenone, } \\
\text { cryptopleurine, } \\
\text { secophenanthroqlinolizidine } \\
{[174] \text {. }}\end{array}$ & $\begin{array}{l}\text { Leaf juice is applied on } \\
\text { cuts and wounds [174]. }\end{array}$ \\
\hline 17. & $\begin{array}{l}\text { P. } \otimes \text { Andrographis } \\
\text { paniculata (Burm. f.) } \\
\text { Wall. ex Nees } \\
\text { Acanthaceae Creat } \\
\text { (E), Kitatikta, Kalmegh } \\
\text { (N), Bhunimbah (S). } \\
\text { Syn. A. subspathulata } \\
\text { Clarke. }\end{array}$ & $\begin{array}{l}\text { Raw plant root } \\
\text { juice is } \\
\text { considered as } \\
\text { antipyretic and } \\
\text { effective against } \\
\text { infections. }\end{array}$ & $\begin{array}{l}\text { Plant is useful for } \\
\text { curing malarial and } \\
\text { intermittent fever, } \\
\text { dysentery and liver } \\
\text { disorders [32]. }\end{array}$ & $\begin{array}{l}\text { Plant is effective for } \\
\text { dermatologial } \\
\text { diseases [27]. It is } \\
\text { useful in malarial } \\
\text { and intermittent } \\
\text { fevers [175]. }\end{array}$ & $\begin{array}{l}\text { Andrographolide, caffeic } \\
\text { acid, kalmeghin, } \\
\text { neoandrographolide, } \\
\text { panicolide. }\end{array}$ & $\begin{array}{l}\text { Plant is } \\
\text { immunostimulant [58], } \\
\text { anti-inflammatory [53], } \\
\text { antibacterial [59], } \\
\text { analgesic [60] and } \\
\text { antiprotozoal [61]. } \\
\text { Kalmeghin increases } \\
\text { biliary flow and liver } \\
\text { weight [175] and aids } \\
\text { intestinal digestion } \\
\text { [176] and liver } \\
\text { protection [177,178]. }\end{array}$ \\
\hline 18. & $\begin{array}{l}\text {-Sapium insigne } \\
\text { (Royle) Benth. ex. } \\
\text { Hook. f. } \\
\text { Euphorbiaceae } \\
\text { Tallow tree (E), Khirro } \\
\text { (N). }\end{array}$ & $\begin{array}{l}\text { Milky latex is } \\
\text { skin irritant and } \\
\text { sprayed as fish } \\
\text { poison in } \\
\text { stream and } \\
\text { tributaries. }\end{array}$ & $\begin{array}{l}\text { Bark latex is used to } \\
\text { dispel works and } \\
\text { germs for livestock } \\
\text { [33]. }\end{array}$ & $\begin{array}{l}\text { Latex is vesicant } \\
{[147] .}\end{array}$ & $\begin{array}{l}\text { Corilagin, guijaverin, } \\
\text { nicotiflorin, phorbol esters, } \\
\text { quinic acid, rutin, scopolin } \\
{[179] .}\end{array}$ & $\begin{array}{l}\text { Leaf extract is used for } \\
\text { snake bite [180]. }\end{array}$ \\
\hline 19. & $\begin{array}{l}\text { QVitex negundo L. } \\
\text { Verbenaceae } \\
\text { Negunda Chaste tree } \\
\text { (E), Simali }(N) \text {, } \\
\text { Nirgundhi }(L), \\
\text { Shephali (S). } \\
\text { Syn. V. cannabilifolia } \\
\text { Sieb. \& Zucc. }\end{array}$ & $\begin{array}{l}\text { Leaf juice is } \\
\text { useful in } \\
\text { stomachache. }\end{array}$ & $\begin{array}{l}\text { Plant juice is used for } \\
\text { headache [28]. Leaf } \\
\text { juice is useful for } \\
\text { gastric troubles [30] } \\
\text { and used for common } \\
\text { cold, fever and } \\
\text { dermatitis [31]. }\end{array}$ & $\begin{array}{l}\text { Plant is used for } \\
\text { fever and nerve } \\
\text { defects [21]. }\end{array}$ & $\begin{array}{l}\text { Agnusid, aucubin, casticin, } \\
\text { hentriacontane, luteolin } \\
\text { nishidine, peduncularisid, } \\
\text { vanilic acid, vitexin }[100,181] \text {. }\end{array}$ & $\begin{array}{l}\text { Leaf extract shows } \\
\text { antibacterial [103] and } \\
\text { weak antifungal } \\
\text { properties [104] and it } \\
\text { is good for lowering } \\
\text { blood glucose levels } \\
\text { [105], cancer treatment } \\
{[106] \text { and acne control }} \\
{[107] \text {. It is useful for }} \\
\text { inhibition of edema } \\
{[108,109] \text { and tracheal }} \\
\text { contraction [110]. }\end{array}$ \\
\hline 20. & $\begin{array}{l}\text { } \otimes \text { Skimmia anquetilia } \\
\text { N.P. Taylor \& Airy } \\
\text { Shaw Rutaceae Chillo } \\
\text { pate (L), Narpati (N). }\end{array}$ & $\begin{array}{l}\text { Leaf infusion is } \\
\text { taken for } \\
\text { headache and } \\
\text { for freshness. }\end{array}$ & $\begin{array}{l}\text { Leaves are aromatic } \\
\text { and used for headache } \\
\text { and general fever } \\
{[15,33] \text {. }}\end{array}$ & - & $\begin{array}{l}\text { Linalool, geraniol, pinene, } \\
\text { scopoletin, skimmianine, } \\
\text { umbelliferone }[181,182] \text {. }\end{array}$ & $\begin{array}{l}\text { Linalool could possess } \\
\text { anxiolytic effect [137]. }\end{array}$ \\
\hline 21. & $\begin{array}{l}\text { QPersicaria barbata } \\
\text { (L.) Hara } \\
\text { Polygonaceae Pirrhe } \\
\text { (N). } \\
\text { Syn. Polygonum } \\
\text { barbata Linn. }\end{array}$ & $\begin{array}{l}\text { Stem juice is } \\
\text { useful for boils } \\
\text { and pimples. }\end{array}$ & $\begin{array}{l}\text { Root paste is applied } \\
\text { on the scabies, } \\
\text { wounds and swollen } \\
\text { parts }[28,30] \text {. }\end{array}$ & $\begin{array}{l}\text { Stem decoction is } \\
\text { useful for ulcers } \\
\text { [147]. }\end{array}$ & - & $\begin{array}{l}\text { Leaves are astringent, } \\
\text { rubifacient and } \\
\text { vermifuge [183]. Plant } \\
\text { decoction is used to } \\
\text { relieve pain and } \\
\text { rheumatism [184]. }\end{array}$ \\
\hline
\end{tabular}


Table 1: Major uses of the medicinal plants, their chemical constituents, and latest common pharmacological findings (species are in order of references) (Continued)

\begin{tabular}{|c|c|c|c|c|c|c|}
\hline 22. & $\begin{array}{l}\text { V.Bauhinia variegata } \\
\text { L. Fabaceae } \\
\text { Mountain ebony (E), } \\
\text { Koiralo (N), Kachnar, } \\
\text { Kovidarah (S). } \\
\text { Syn. B. candida Ait. }\end{array}$ & $\begin{array}{l}\text { Flower and } \\
\text { floral buds are } \\
\text { eaten regularly } \\
\text { to cure } \\
\text { leucorrhoea and } \\
\text { mumps. }\end{array}$ & $\begin{array}{l}\text { Flower juice is taken } \\
\text { for dysentery and } \\
\text { diarrhea [30]. Dried } \\
\text { flowers are given for } \\
\text { diarrhea, dysentery and } \\
\text { piles [31]. Fresh flowers } \\
\text { are used as laxative } \\
\text { [32]. }\end{array}$ & $\begin{array}{l}\text { Flowers are } \\
\text { astringent and used } \\
\text { for diarrhea and } \\
\text { hemorrhage [21]. }\end{array}$ & $\begin{array}{l}\text { Butein, hentriacontane, } \\
\text { lupeol, nicotiflorin, } \\
\text { octacosanol, } \\
\text { rhamnopyranoside. }\end{array}$ & $\begin{array}{l}\text { Methanol extract of } B \text {. } \\
\text { variegata bark showed } \\
\text { the most remarkable } \\
\text { activity as antimicrobial } \\
{[185] \text { and anticancer }} \\
\text { [186]. }\end{array}$ \\
\hline 23. & $\begin{array}{l}\text { Ficus religiosa Linn. } \\
\text { Moraceae Peepal tree } \\
\text { (E), Pipal (N), Aswatha } \\
\text { (S). }\end{array}$ & $\begin{array}{l}\text { Bark juice is } \\
\text { applied for } \\
\text { paralysis. }\end{array}$ & $\begin{array}{l}\text { Bark is astringent, and } \\
\text { its decoction is given } \\
\text { for gonorrhoea and } \\
\text { skin disease }[30,31] \text {. }\end{array}$ & $\begin{array}{l}\text { Bark is astringent, } \\
\text { and used for } \\
\text { hemorrhage and } \\
\text { healing external } \\
\text { wounds [21]. }\end{array}$ & $\begin{array}{l}\text { Phytosterolin, vitamin K, } \\
\text { tannins. }\end{array}$ & $\begin{array}{l}\text { Methanolic extract of } \\
\text { stem bark is useful for } \\
\text { memory longevity } \\
\text { [187] and used as an } \\
\text { analgesic [188]. } \\
\text { Phytosterolin is CNS } \\
\text { stimulant and } \\
\text { hypoglycemic [189]. }\end{array}$ \\
\hline 24. & $\begin{array}{l}\text { - } \otimes \text { Equisetum diffusum } \\
\text { D. Don Equisetaceae } \\
\text { Spreading horsetail } \\
\text { (E), Ankhle jhar (L), } \\
\text { Kurkure (N), 0555/00. }\end{array}$ & $\begin{array}{l}\text { Plant stem juice } \\
\text { is given for } \\
\text { gonorrhea. }\end{array}$ & $\begin{array}{l}\text { Plant root juice is } \\
\text { given for urinary } \\
\text { troubles [30], sprains, } \\
\text { fractures, burns and } \\
\text { scabies [33]. }\end{array}$ & $\begin{array}{l}\text { Plant is diuretic and } \\
\text { useful for gonorrhea } \\
\text { [147]. }\end{array}$ & $\begin{array}{l}\text { Apigenin, ascorbic acid, } \\
\text { equisetolic acid, folic acid, } \\
\text { kaemferol, niacin, silic acid } \\
{[101,190] \text {. }}\end{array}$ & $\begin{array}{l}\text { Methanolic plant } \\
\text { extract shows good } \\
\text { free radical scavenging } \\
\text { activity [191]. }\end{array}$ \\
\hline 25. & $\begin{array}{l}\text { PParnassia nubicola } \\
\text { Wall. Parnassiaceae } \\
\text { Mamira (N), 205/00. }\end{array}$ & $\begin{array}{l}\text { Root paste is } \\
\text { applied for eye } \\
\text { inflammation. }\end{array}$ & $\begin{array}{l}\text { Root paste is useful for } \\
\text { wounds [30], body } \\
\text { ache, headache, and } \\
\text { eye problems }[15,33] \text {. }\end{array}$ & - & - & $\begin{array}{l}\text { Methanolic root extract } \\
\text { showed moderate anti- } \\
\text { inflammatory effect } \\
\text { [192]. }\end{array}$ \\
\hline 26. & $\begin{array}{l}\text { - } \otimes \text { Myrica esculenta } \\
\text { Buch.-Ham. ex D.Don } \\
\text { Myricaceae Box } \\
\text { myrtle Bay berry, (E), } \\
\text { Kafal (N), Kumbhi, } \\
\text { Kaidaryama (S), } \\
\text { 567/00. } \\
\text { Syn. M. fraquhariana } \\
\text { Wall. }\end{array}$ & $\begin{array}{l}\text { Fruits are eaten } \\
\text { for dysentery } \\
\text { and bark } \\
\text { decoction is } \\
\text { given for } \\
\text { bronchitis. }\end{array}$ & $\begin{array}{l}\text { Bark is useful for } \\
\text { cough, asthma, } \\
\text { sinusitis [31] and } \\
\text { chronic bronchitis, } \\
\text { diarrhea and dysentery } \\
\text { [32]. }\end{array}$ & $\begin{array}{l}\text { Bark decoction is } \\
\text { useful for asthma, } \\
\text { dysentery and lung } \\
\text { affections [147]. }\end{array}$ & $\begin{array}{l}\text { Friedelin, myricanone, } \\
\text { myricadiol, myricanol, } \\
\text { myricitrin, taraxerol [181]. }\end{array}$ & $\begin{array}{l}\text { Methanolic root extract } \\
\text { showed potent anti- } \\
\text { inflammatory effect } \\
\text { [193]. }\end{array}$ \\
\hline 27. & $\begin{array}{l}\text { Arisaema flavum } \\
\text { (Forsk.) Schott } \\
\text { Araceae Banko (N), } \\
\text { 562/00. }\end{array}$ & $\begin{array}{l}\text { Rhizome juice is } \\
\text { applied on } \\
\text { earache and } \\
\text { skin diseases. } \\
\text { Young shoots } \\
\text { are cooked as } \\
\text { vegetable. }\end{array}$ & $\begin{array}{l}\text { Leaves are consumed } \\
\text { as a laxative [15]. } \\
\text { Tubers are used for } \\
\text { toothache, } \\
\text { stomachache and } \\
\text { chest infection [29]. }\end{array}$ & - & $\begin{array}{l}\text { Alanine, ariseminone, } \\
\text { asparagine, cysteine, glycine, } \\
\text { norvaline, ornithine [100]. }\end{array}$ & $\begin{array}{l}\text { Methanolic tuber } \\
\text { extracts revealed weak } \\
\text { antiviral property [194]. }\end{array}$ \\
\hline 28. & $\begin{array}{l}\text { P. } \otimes \text { Azadirachta indica } \\
\text { A. Juss. Meliaceae } \\
\text { Neem tree, Margosa } \\
\text { tree (E), Neem (N), } \\
\text { Aristha, Nimbah (S). } \\
\text { Syn. Melia azadirachta } \\
\text { L. }\end{array}$ & $\begin{array}{l}\text { Both raw and } \\
\text { dried leaves are } \\
\text { used for fever } \\
\text { and blood } \\
\text { disorders (no } \\
\text { other } \\
\text { information } \\
\text { given). }\end{array}$ & $\begin{array}{l}\text { Leaves are } \\
\text { anthelmintic and good } \\
\text { for cough, asthma, } \\
\text { piles and urinary } \\
\text { discharge [31]. They } \\
\text { are used for malarial } \\
\text { and intermittent fever, } \\
\text { liver complaint and } \\
\text { diabetes [32]. }\end{array}$ & $\begin{array}{l}\text { Leaves are used for } \\
\text { skin diseases and } \\
\text { blood circulatory } \\
\text { defects [21] and } \\
\text { useful for ulcers, } \\
\text { sores, swellings and } \\
\text { wounds [25]. }\end{array}$ & $\begin{array}{l}\text { Azadirachtin, gedunin, } \\
\text { limonoids, linoleic acid, } \\
\text { nimbin, nimbidin, oleic acid, } \\
\text { stearic acid [195]. }\end{array}$ & $\begin{array}{l}\text { Nimbidin possesses } \\
\text { anti-inflammatory } \\
\text { [170], analgesic [196], } \\
\text { antipyretic [49], } \\
\text { antiulcer, } \\
\text { anticholinergic, } \\
\text { antihistaminic and } \\
\text { antinicotinic effects } \\
\text { [197]. Bark extract is } \\
\text { useful as antibacterial } \\
\text { [198] and } \\
\text { antisplasmodial [199]. } \\
\text { Leaf extract promotes } \\
\text { wound healing, ulcer } \\
\text { protective [200] and } \\
\text { hypoglycaemic [201]. }\end{array}$ \\
\hline
\end{tabular}


Table 1: Major uses of the medicinal plants, their chemical constituents, and latest common pharmacological findings (species are in order of references) (Continued)

\begin{tabular}{|c|c|c|c|c|c|}
\hline 29. & $\begin{array}{l}\text { ט. } \otimes \text { Anisomeles indica } \\
\text { (L.) Kuntze Lamiaceae } \\
\text { Malabar catmint (E), } \\
\text { Ratocharpate (N), 167/ } \\
\text { 00. Syn. A. ovata R.Br. }\end{array}$ & $\begin{array}{l}\text { Leaf extract is } \\
\text { useful for } \\
\text { urinary } \\
\text { complaints (no } \\
\text { other } \\
\text { information } \\
\text { given). }\end{array}$ & $\begin{array}{l}\text { Plant is astringent, } \\
\text { tonic and its juice is } \\
\text { useful for urinary } \\
\text { affections }[30,33] \text {. }\end{array}$ & $\begin{array}{l}\text { Plant is taken for } \\
\text { uterine affections } \\
\text { [147]. }\end{array}$ & $\begin{array}{l}\text { Alanine, anisomelic acid, } \\
\text { apigenin, amyrin, } \beta \\
\text { sitosterol, behemic acid, } \\
\text { betulin, cerotic acid, } \\
\text { malabaric acid, ovatodiolide } \\
\text { pedallitin, stearic acid, } \\
\text { stigmasterol }[27,181] .\end{array}$ \\
\hline
\end{tabular}

Ovatodiolide and pedallitin of Anisomeles indica is good antiinflammatory [202]. Pre-flowering plant water extract is analgesic [203]. Ethanolic leaf extract is strong antiviral [204] and anti HIV potential [205].

\begin{tabular}{|c|c|c|c|c|c|c|}
\hline 30. & $\begin{array}{l}\text { } \otimes \text { Lichen species } \\
\text { Lichen Lichen (E), } \\
\text { Jhyau (N), KU 07267. }\end{array}$ & $\begin{array}{l}\text { Lichen extract } \\
\text { and decoction } \\
\text { is applied to } \\
\text { treat moles. }\end{array}$ & $\begin{array}{l}\text { Paste is used as } \\
\text { ointment and } \\
\text { antibiotic for cuts and } \\
\text { wounds [31]. }\end{array}$ & $\begin{array}{l}\text { Lichen is cardiac } \\
\text { tonic [147]. }\end{array}$ & $\begin{array}{l}\text { Atranorin, barbatic acid, } \\
\text { norstictic acid, usnic acid, } \\
\text { vulpinic acid [112]. }\end{array}$ & $\begin{array}{l}\text { Parmelia species are } \\
\text { antimicrobial and used } \\
\text { to treat warts }[118,119] \\
\text { and cranial diseases } \\
\text { [206]. }\end{array}$ \\
\hline 31. & $\begin{array}{l}\text { - } \otimes \text { Abies spectabilis (D. } \\
\text { Don) Mirb. Pinaceae } \\
\text { Himalayan Silver Fir } \\
\text { (E), Gobre Salla }(L, N) \text {, } \\
\text { Talispatra (N,S). } \\
\text { Syn. Pinus tinctoria } \\
\text { Wallich ex D. Don }\end{array}$ & $\begin{array}{l}\text { Leaves are } \\
\text { sniffed for } \\
\text { cough and cold. }\end{array}$ & $\begin{array}{l}\text { Plant needle oil is } \\
\text { valued for colds and } \\
\text { nasal congestions [30]. } \\
\text { Leaf decoction is used } \\
\text { for cough and } \\
\text { bronchitis [32]. }\end{array}$ & $\begin{array}{l}\text { Plant is considered } \\
\text { to be used for } \\
\text { asthma, bronchitis, } \\
\text { cough, rheumatism, } \\
\text { anorexia, abdominal } \\
\text { lump, indigestion } \\
\text { and tuberculosis [22]. }\end{array}$ & $\begin{array}{l}\beta \text { pinene, camphene, } \\
\text { carvone, catechin, } \\
\text { catechutannic acid, } \\
\text { ephedrine, taxine, taxinine } \\
{[24,32] .}\end{array}$ & $\begin{array}{l}\text { Pinene of Abies leaves } \\
\text { is anti-inflammatory } \\
\text { and antidepressant } \\
\text { [207]. Plant extract } \\
\text { with the ephedrine } \\
\text { should always be used } \\
\text { with caution in } \\
\text { patients with } \\
\text { hypertension }[38,208] \text {. }\end{array}$ \\
\hline 32. & $\begin{array}{l}\text { } \otimes \text { Quercus lanata } \\
\text { Sm. Fagaceae Wooly } \\
\text { oak (E), Latyaz (L), } \\
\text { Baanjh }(\mathrm{N}) \text {. } \\
\text { Syn. Q. lanuginosa D. } \\
\text { Don }\end{array}$ & $\begin{array}{l}\text { Heart wood is } \\
\text { taken as tea } \\
\text { and it is laxative } \\
\text { in nature. }\end{array}$ & $\begin{array}{l}\text { Resin is useful for } \\
\text { soothing body ache } \\
\text { [30]. Dry resin is taken } \\
\text { to treat dysentery [33]. }\end{array}$ & - & $\begin{array}{l}\text { Cyclobalanone, friedelin, } \\
\text { pelagonodin, sitosterol, } \\
\text { tannins }[100] .\end{array}$ & $\begin{array}{l}\text { Resin and bark tannin } \\
\text { is anti-inflammatory } \\
{[122,209] \text {. }}\end{array}$ \\
\hline 33. & $\begin{array}{l}\text { Solena heterophylla } \\
\text { Lour. Cucurbitaceae } \\
\text { Ban kankri (N) KU } \\
07255 . \\
\text { Syn. Melothria } \\
\text { heterophylla L. }\end{array}$ & $\begin{array}{l}\text { Fruits are eaten } \\
\text { for common } \\
\text { cold and } \\
\text { pneumonia of } \\
\text { child. }\end{array}$ & $\begin{array}{l}\text { Fruits are useful for } \\
\text { throat pain and fever } \\
\text { [28]. }\end{array}$ & $\begin{array}{l}\text { Root juice is useful } \\
\text { for dysuria and } \\
\text { spermatorrhoea } \\
\text { [147]. }\end{array}$ & $\begin{array}{l}\text { Behemic acid, columbin, } \\
\text { lignoceric acid [210]. }\end{array}$ & $\begin{array}{l}\text { Plant extract is hepato- } \\
\text { protective and plant } \\
\text { coumarin and } \\
\text { flavonoids inhibit } \\
\text { platelet aggregation } \\
\text { [211]. }\end{array}$ \\
\hline 34. & $\begin{array}{l}\text { Osmanthes fragrans } \\
\text { Lour. Oleaceae Tree } \\
\text { Jasmine (E), Siringe } \\
\text { (N), KU 07244. } \\
\text { Syn. O. acuminatus } \\
\text { (Wall.) Nakai }\end{array}$ & $\begin{array}{l}\text { Leaf juice is } \\
\text { taken for fever } \\
\text { and cold. }\end{array}$ & $\begin{array}{l}\text { Stem bark is valued for } \\
\text { boils, cough and } \\
\text { retinitis }[30,33] \text {. }\end{array}$ & $\begin{array}{l}\text { Leaf juice is tonic } \\
\text { [147]. }\end{array}$ & $\begin{array}{l}\text { Caffeic acid, catechin, gallic } \\
\text { acid, leuropin, ligustroside, } \\
\text { luteolin, oleanolic acid, } \\
\text { phillyrin, succinic acid [100]. }\end{array}$ & $\begin{array}{l}\text { Plant extract has } \\
\text { antioxidant and } \\
\text { melanogenesis } \\
\text { inhibitory effects } \\
\text { [212,213] and } \\
\text { neuroprotective } \\
\text { property [214]. }\end{array}$ \\
\hline 36. & $\begin{array}{l}\text { Curcuma angustifolia } \\
\text { Roxb. Zingiberaceae } \\
\text { Zeodory, Turmeric (E), } \\
\text { Sathi, Kachur (L), Haldi } \\
\text { (N) Ban haldi, Haridra, } \\
\text { Harita (S) KU } 07259 \text {. } \\
\text { Syn. C. longa L. }\end{array}$ & $\begin{array}{l}\text { Rhizome paste } \\
\text { is externally } \\
\text { applied for } \\
\text { paralysis. }\end{array}$ & $\begin{array}{l}\text { Rhizome paste is } \\
\text { externally applied to } \\
\text { bruises, pains and } \\
\text { injuries [31]. }\end{array}$ & $\begin{array}{l}\text { Tuber is used for } \\
\text { skin diseases and } \\
\text { urinary complaints } \\
\text { [21]. Fresh tuber } \\
\text { juice is antiparasitic } \\
\text { and useful for skin } \\
\text { affections [25]. }\end{array}$ & $\begin{array}{l}\text { Anthraquinone, borneol, } \\
\text { campesterol, camphene, } \\
\text { caryoplhylene, cineole, } \\
\text { curcumin curdione, } \\
\text { curzerenone, curlone, } \\
\text { eugenol, limonene, linalool, } \\
\text { terpinene }[100,210] \text {. }\end{array}$ & $\begin{array}{l}\text { Curcumin is anti- } \\
\text { inflammatory [78-80], } \\
\text { antiviral [82], antifungal } \\
\text { [83], antispasmodic } \\
\text { [86] and hepato- } \\
\text { protective [87]. It is } \\
\text { also useful for AIDS } \\
\text { [90,91] control blood } \\
\text { pressure [93]. Plant } \\
\text { extract is } \\
\text { antimutagenic [216]. }\end{array}$ \\
\hline
\end{tabular}


Table 1: Major uses of the medicinal plants, their chemical constituents, and latest common pharmacological findings (species are in order of references) (Continued)

\begin{tabular}{|c|c|c|c|c|c|c|}
\hline 37. & $\begin{array}{l}\text { - Evolvulus alsinoides } \\
\text { (L.) Linn. Fabaceae } \\
\text { Aankuri phul (N), } \\
\text { Visnukravita (S). }\end{array}$ & $\begin{array}{l}\text { Decoction of } \\
\text { plant is taken } \\
\text { for increase } \\
\text { memory. }\end{array}$ & $\begin{array}{l}\text { Ash of the plant is } \\
\text { spread on boils and } \\
\text { pimples [30]. Plant } \\
\text { paste is applied on } \\
\text { scorpion sting, burns } \\
\text { and scabies [33]. }\end{array}$ & $\begin{array}{l}\text { Plant is brain } \\
\text { stimulant, } \\
\text { aphrodisiac, } \\
\text { anthelmintic and } \\
\text { antidysenteric [217]. }\end{array}$ & $\begin{array}{l}\beta \text { sitosterol, betaine, } \\
\text { evolvine, linoleic acid, oleic } \\
\text { acid, stearic acid [181]. }\end{array}$ & $\begin{array}{l}\text { Plant extract is } \\
\text { analgesic, CNS } \\
\text { depressant [218] and } \\
\text { has anthelmintic, } \\
\text { wound healing } \\
\text { [219,220] and } \\
\text { antibacterial properties } \\
\text { [221]. }\end{array}$ \\
\hline 38. & $\begin{array}{l}\text { Sterculia villosa Roxb. } \\
\text { Sterculiaceae } \\
\text { Sterculia, Odaal tree } \\
\text { (E), Odaal (N). } \\
\text { Syn. Firmiana fulgens } \\
\text { (Wall. Ex Master) } \\
\text { Corner }\end{array}$ & $\begin{array}{l}\text { Stem bark is } \\
\text { considered as } \\
\text { an astringent. It } \\
\text { is used for } \\
\text { cooking breads. }\end{array}$ & $\begin{array}{l}\text { White exudes of the } \\
\text { tree is used for throat } \\
\text { infection. Root infusion } \\
\text { is taken as food } \\
\text { adjunct [33]. }\end{array}$ & - & - & $\begin{array}{l}\text { Plant extract is useful } \\
\text { for skin disease [222]. }\end{array}$ \\
\hline 39. & $\begin{array}{l}\text { QPyracantha } \\
\text { crenulata (D. Don) M. } \\
\text { Roem. Rosaceae } \\
\text { Nepali white thorn (E), } \\
\text { Ghangaru (N). }\end{array}$ & $\begin{array}{l}\text { Fruits are eaten } \\
\text { for dysentery. }\end{array}$ & $\begin{array}{l}\text { Fruit powder is used } \\
\text { for blood dysentery } \\
{[30,33] \text {. }}\end{array}$ & - & $\begin{array}{l}\text { Pyracrenic acid, sorbitol, } \\
\text { tannin [223]. }\end{array}$ & $\begin{array}{l}\text { Pyracrenic acid is anti- } \\
\text { inflammatory [223]. }\end{array}$ \\
\hline 40. & $\begin{array}{l}\text { PPhytolacca acinosa } \\
\text { Phytolaccaceae } \\
\text { Pokeberry (E), Jaringo } \\
\text { (N). } \\
\text { Syn. P. latbenia (Moq.) } \\
\text { H. Walter }\end{array}$ & $\begin{array}{l}\text { Vegetable is } \\
\text { consumed for } \\
\text { body ache (no } \\
\text { other } \\
\text { information } \\
\text { given). }\end{array}$ & $\begin{array}{l}\text { Plant is narcotic and } \\
\text { purgative in properties } \\
\text { [30]. }\end{array}$ & - & $\begin{array}{l}\text { Acinosolic acid, jailigonic } \\
\text { acid, lectins, oleanolic acid, } \\
\text { myricadol, phytolaccagenin, } \\
\text { spergulagenic acid, zonarol } \\
{[32,100] \text {. }}\end{array}$ & $\begin{array}{l}\text { Root extract shows } \\
\text { weak triosinase } \\
\text { inhibitory activity i.e. } \\
\text { Skin whitening [224]. } \\
\text { Saponin extracts from } \\
\text { Phytolacca } \\
\text { demonstrated anti- } \\
\text { inflammatory [225], } \\
\text { antifungal [226] and } \\
\text { anti-viral effects [227]. }\end{array}$ \\
\hline 41. & $\begin{array}{l}\text { Smilax aspera Wall. } \\
\text { Smilacaceae Rough } \\
\text { birdweed (E), } \\
\text { Chopchini (L), } \\
\text { Kukurdaina (N), 101/ } \\
\text { 00. } \\
\text { Syn. S. capitata Buch.- } \\
\text { Ham. ex D.Don }\end{array}$ & $\begin{array}{l}\text { Root decoction } \\
\text { is used for } \\
\text { venereal } \\
\text { disease. }\end{array}$ & $\begin{array}{l}\text { Root extract cures } \\
\text { scabies [30] and } \\
\text { purifies blood [33]. }\end{array}$ & - & $\begin{array}{l}\text { Asparagenin, engelitin, } \\
\text { parallin, pseudogenin, } \\
\text { rutinoside, sarsapogenin, } \\
\text { smilogenin, tannin }[126,228] \text {. }\end{array}$ & $\begin{array}{l}\text { Stem juice is used for } \\
\text { dropsy and gout [229]. } \\
\text { Rutinoside is cancer } \\
\text { inhibitory [230]. }\end{array}$ \\
\hline 42. & $\begin{array}{l}\text { } \otimes \text { Ficus auriculata } \\
\text { Lour. Moraceae Eve's } \\
\text { apron (E), Timila (N). } \\
\text { Syn. F. roxburghii Wall }\end{array}$ & $\begin{array}{l}\text { Stem juice is } \\
\text { considered } \\
\text { effective against } \\
\text { diarrhea and } \\
\text { fruits are } \\
\text { consumed for } \\
\text { dysentery. }\end{array}$ & $\begin{array}{l}\text { Bark juice and roasted } \\
\text { figs are useful for } \\
\text { diarrhea and dysentery } \\
{[28,30] \text {. }}\end{array}$ & - & $\begin{array}{l}\beta \text { sitosterol, epifriedelanol, } \\
\text { friedelin [100]. }\end{array}$ & $\begin{array}{l}\text { Tannins of the bark } \\
\text { extract may reveal anti- } \\
\text { inflammatory and } \\
\text { analgesic activities } \\
\text { [231]. }\end{array}$ \\
\hline 43. & $\begin{array}{l}\text { v. } \otimes \text { Euphorbia hirta } \\
\text { Linn. Euphorbiaceae } \\
\text { Snake weed, Asthma } \\
\text { weed (E), Dudhi jhar } \\
\text { (N), Pusitoba (S). Syn. } \\
\text { E. pilulifera L. }\end{array}$ & $\begin{array}{l}\text { Plant latex is } \\
\text { applied for cuts. } \\
\text { Plant juice is } \\
\text { applied in } \\
\text { asthma and } \\
\text { diarrhea. }\end{array}$ & $\begin{array}{l}\text { Plant juice is useful for } \\
\text { boils, cuts and wounds } \\
\text { [30] and is considered } \\
\text { to be used in } \\
\text { treatment of asthma } \\
\text { and cough [32]. }\end{array}$ & $\begin{array}{l}\text { It is useful for } \\
\text { cardiovascular } \\
\text { complaints, asthma } \\
\text { and spleen disorders } \\
\text { [27]. }\end{array}$ & $\begin{array}{l}\text { Galloylquinic acid, Phorbol } \\
\text { acid, leucocyanidol, } \\
\text { quercitol, camphol, } \\
\text { quercetin, chlorophenolic } \\
\text { acid, shikimic acid [100]. }\end{array}$ & $\begin{array}{l}\text { Plant alkaloid is } \\
\text { effective in broncho- } \\
\text { dilation [27], and used } \\
\text { as an antispasmodic, } \\
\text { antiasthmatic, } \\
\text { expectorant, } \\
\text { anticatarrhal [74,232]. } \\
\text { The methanol extract } \\
\text { of flowers has } \\
\text { antibacterial activity } \\
\text { [75]. }\end{array}$ \\
\hline 44. & $\begin{array}{l}\text { QJurinea dolomiea } \\
\text { Bioss. Asteraceae } \\
\text { Bhutkes (N) KU } 07266 . \\
\text { Syn. Carduus } \\
\text { macrocephalus Wall. }\end{array}$ & $\begin{array}{l}\text { Root decoction } \\
\text { is taken in } \\
\text { stomachache } \\
\text { and diarrhea. }\end{array}$ & $\begin{array}{l}\text { Root is used for } \\
\text { stomachache and } \\
\text { diarrhea [29]. Root } \\
\text { juice is taken for } \\
\text { cough and cold [30]. }\end{array}$ & - & Vasicine. & $\begin{array}{l}\text { Vasicine exhibited } \\
\text { strong respiratory } \\
\text { stimulant, moderate } \\
\text { hypotensive, cardiac- } \\
\text { depressant and } \\
\text { abortifacient [233]. }\end{array}$ \\
\hline
\end{tabular}


Table 1: Major uses of the medicinal plants, their chemical constituents, and latest common pharmacological findings (species are in order of references) (Continued)

\begin{tabular}{|c|c|c|c|c|c|c|}
\hline 45. & $\begin{array}{l}\text { V. } \otimes \text { Tinospora sinensis } \\
\text { (Lour.) Merr. } \\
\text { Menispermaceae } \\
\text { Heart leaved } \\
\text { Moonseed (E), Gurjo } \\
\text { (N), Guduchi, } \\
\text { Amritavali (S). } \\
\text { Syn. T. cordifolia auct. } \\
\text { non L. }\end{array}$ & $\begin{array}{l}\text { Dilute stem } \\
\text { juice is drunk } \\
\text { for diabetes. }\end{array}$ & $\begin{array}{l}\text { Stem juice is valued } \\
\text { for dysentery, diabetes, } \\
\text { gonorrhoea [31], } \\
\text { genital disorders and } \\
\text { diabetes [32]. }\end{array}$ & $\begin{array}{l}\text { Stem is used for } \\
\text { urinary diseases and } \\
\text { hepatitis [21]. Stem } \\
\text { juice is antipyretic, } \\
\text { antiperiodic and } \\
\text { alterative [25]. }\end{array}$ & $\begin{array}{l}\text { Berberine, choline, cordifol, } \\
\text { isocolumbin, jatrorhizine, } \\
\text { magnoflorine, palmatine, } \\
\text { tembeterine, tinosporin, } \\
\text { tinosporide [27]. }\end{array}$ & $\begin{array}{l}\text { Water extract } \\
\text { (berberine) is } \\
\text { antipyretic [234] and } \\
\text { antidiabetic [66] due to } \\
\text { berberine [68] but } \\
\text { higher doses may be } \\
\text { antagonistic [69]. Plant } \\
\text { extract is hepato- } \\
\text { protective [235], } \\
\text { hypoglycaemic [67] } \\
\text { and immunostimulant } \\
\text { [236]. }\end{array}$ \\
\hline 46. & $\begin{array}{l}\text { PBetula utilis D.Don } \\
\text { Betulaceae } \\
\text { Himalayan Birch (E), } \\
\text { Bhuj pat (L), Bhojpatra } \\
\text { (N), Bhurjah, } \\
\text { Lekhyapatrak (S), 556/ } \\
\text { 00. } \\
\text { Syn. B. bhojpattra } \\
\text { Lindl. }\end{array}$ & $\begin{array}{l}\text { Bark decoction } \\
\text { is useful for } \\
\text { sore throat. }\end{array}$ & $\begin{array}{l}\text { Bark is used for } \\
\text { bacterial infections, } \\
\text { skin diseases, } \\
\text { bronchitis cough } \\
{[15,33] \text {, and cuts, }} \\
\text { wounds and burns } \\
{[30] \text {. }}\end{array}$ & $\begin{array}{l}\text { Bark is astringent } \\
\text { and its fume is used } \\
\text { for easy delivery and } \\
\text { placenta expels [21]. }\end{array}$ & $\begin{array}{l}\text { Betulin, karachic acid, } \\
\text { leucocyanidin, lupenone, } \\
\text { lupeol, oleanolic acid. }\end{array}$ & $\begin{array}{l}\text { Bark extract is } \\
\text { antiseptic [100]. } \\
\text { Betulinic acid is anti- } \\
\text { inflammatory [237]. }\end{array}$ \\
\hline 47. & $\begin{array}{l}\text { P. } \otimes \text { Aesculus indica } \\
\text { (Colebr. ex Cambess.) } \\
\text { Hook. } \\
\text { Hippocastanaceae } \\
\text { Horse chesnut (E), } \\
\text { Panger, Karu (N), } \\
\text { Naaru (S), Horse 563/ } \\
00 .\end{array}$ & $\begin{array}{l}\text { Seed oil is } \\
\text { valued for joint } \\
\text { pain and skin } \\
\text { problems (no } \\
\text { other } \\
\text { information } \\
\text { given). }\end{array}$ & $\begin{array}{l}\text { Seed oil is used for } \\
\text { scabies and skin } \\
\text { diseases }[15,30,33] \text {. }\end{array}$ & $\begin{array}{l}\text { Bark is used for } \\
\text { dislocated joints and } \\
\text { seed oil is } \\
\text { considered to be } \\
\text { used for rheumatism } \\
\text { [147]. }\end{array}$ & $\begin{array}{l}\text { Aescin, aesculuside, } \\
\text { astragalin, } \beta \text { sitosterol, } \\
\text { catechol, decanoic acid, } \\
\text { epicatechin, quercetin, rutin, } \\
\text { saponins [100]. }\end{array}$ & $\begin{array}{l}\text { Plant is used for } \\
\text { delaying } \\
\text { hypersensitivity [238]. } \\
\text { Aescin is cardio- } \\
\text { stimulant and anti- } \\
\text { inflammatory [239]. }\end{array}$ \\
\hline 48. & $\begin{array}{l}\text { } \otimes \text { Daphne bholua } \\
\text { Buch.-Ham. ex D.Don } \\
\text { Thymelaeaceae } \\
\text { Nepali paper plant (E), } \\
\text { Gore, Baruwa (L), } \\
\text { Lokta, Kagaj pate (N). } \\
\text { Syn. D. cannabina } \\
\text { Lour. ex Wall. }\end{array}$ & $\begin{array}{l}\text { Seeds are taken } \\
\text { for } \\
\text { stomachache } \\
\text { and } \\
\text { anthelmintic. }\end{array}$ & $\begin{array}{l}\text { Root extract is used for } \\
\text { intestinal disorder and } \\
\text { powered seeds are } \\
\text { taken as an } \\
\text { anthelmintic [28]. }\end{array}$ & - & $\begin{array}{l}\text { Daphnoside, daphnetin, } \\
\text { genkwanin, luteolin, } \\
\text { taraxerol [100]. }\end{array}$ & $\begin{array}{l}\text { Bark decoction is given } \\
\text { to treat fever. Root } \\
\text { juice is anthelmintic } \\
\text { [240]. }\end{array}$ \\
\hline
\end{tabular}

$\mathrm{E}=$ English, $\mathrm{L}=$ Local, $\mathrm{N}=$ Nepali, $\mathrm{S}=$ Sanskrit, Syn. = Synonymous

$\otimes=$ Species's use resembled with the common uses of Ayurveda, $\cdot=$ Species's use resembled with earlier reports, $\boldsymbol{\varphi}=$ Species's use resembled with latest common phytochemical findings

pharmacologically rationale and that of $A$. indica and T. sinensis was folk-based.

Euphorbiaceae species are generally characterized by milky latex [71], and sticky saps are co-carcinogenic, and can cause severe skin irritation and are toxic to livestock and humans [72]. They are rich in active compounds including terpenoids, alkaloids, phenolics and fatty acids, having ethnopharmaceutical uses [73]. Sapium insigne (Euphorbiaceae) is skin irritant, and commonly used as fish poison in study area and throughout Nepal [28]. Both the water and methanol extracts of Euphorbia hirta (Euphorbiaceae) are antibacterial $[74,75]$ and effective as expectorant [76,77] and broncho-dilator [27], which is consistent with the folkloric use in treatment of respiratory complaints.

Pharmacologically, curcumin of Curcuma species (Zingiberaceae) acts as an anti-inflammatory [78-80], antibacterial [81], antiviral [82], antifungal [83], antitumor
[84,85], antispasmodic [86], and hepato-protective [87]. The oxygen radical scavenging activity of curcumin has been implicated in its anti-inflammatory effects $[88,89]$ thus curcumin may prove useful as a drug for arthritis, cancer, HIV [90-92] and high blood pressure [93]. Wide range of pharmacological reports including antibacterial and antiviral complements the folk use to treat paralysis. Rhizome extract of the plant was widely used for skin diseases (bruises, injuries, etc.) in west Nepal [15] and in the Ayurveda [21].

The folk use of Acacia catechu (Fabaceae) wood tea as an expectorant fairly corroborated the pharmacological properties because the tannin and cyanidanol [94,95] of the plant impart astringent activity which helps to recuperate diarrhea. Tannins are also known as antimicrobial [96] and triterpenoids are beneficial for inflammation and cancer [97]. The hepato-protective and hypoglycemic properties of $A$. catechu could be 
attributed to the quercetin [98] and epicatechin [99] respectively. Leaf extracts of Taxus wallichiana (Taxaceae) inhibit pregnancy in rats [22], vitiate blood disorders [100] and control tumor growth [101]. In the study area, Taxus leaf juice is used for treatment of cancer and bronchitis.

Lectins of Cannabis sativa (Cannabaceae) possess haema-gluttinating properties [38] which corroborate the indigenous use of the leaf extract to control bleeding. Crude leaf extract of Vitex negundo (Verbenaceae) is recommended as antitussive and anti-asthma [102], antibacterial [103], antifungal [104], hypoglycemic [105], anti-cancer [106], acne control [107], inhibitor of edema $[108,109]$ to tracheal contraction [110]. However, it did not corroborate the folk use for stomachache but was partially complemented by earlier observations $[30,111]$. The unlike uses of the species after thorough scrutiny, under different medical systems and comparisons pose more research scopes. Several instances are rational behind a certain function of a phytomolecule sometimes inconsistent to the pharmacology and ethnopharmacology. Moreover, while advocating herbal medicine as alternative therapy, toxicity of plants should be borne in mind.

Lichens and their metabolites have manifold biological activity: antiviral, antibiotic [112], antitumor, allergenic, plant growth inhibitory, antiherbivore, ecological roles and enzyme inhibitory $[113,114]$. Usnic acid and vulpunic acid (produced by mycobiont) of lichens are mitotic regulators [115] and own antibiotic properties [116]. Parmelia sulcata lichen manifests antibacterial and antifungal activities $[117,118]$. Use of Parmelia species to treat warts [119] is analogous to its folk use. Folk use of wood tea of Quercus lanata (Fagaceae) as a laxative may verify the actions of tannin. Tannins reveal activities against central nervous system disorders [120] and inflammation $[121,122]$. Further pharmacological evaluation of the extracts of those species which reveal weak pharmacological validities are needed before they can be used as therapeutic potentials.

The compounds which contribute to the antioxidative properties are polyphenols [123], vitamin $C$ [124], $\beta$ carotene [125], anthocyanins [126], and flavonoids [127]. Ellagic acid of Fragaria nubicola (Rosaceae) is also responsible for antioxidant activity [128]. Antioxidants are associated with reduced risk of cancer and cardiovascular diseases [129] and many other ailments [130]. Antimicrobial and anti-inflammatory properties of Fragaria fruit extracts $[101,131]$ are consistent with the folkloric use as remedy for skin diseases and wounds. The usage of root powder of Potentilla fulgens (Rosaceae) as a dentifrice is common in the study area and throughout Nepal $[132,133]$ and it is in accord to the
Ayurvedic uses. However, the usage is yet to be verified pharmacologically.

Wogonin of Scutellaria discolor (Lamiaceae) is considered as a most potent antiviral [134] and anxiolytic [135] compound. Plant root extract is also useful for rheumatism [136]. Whole plant and leaf paste is useful for cuts \& wounds, which probably rationalize the activities of wogonin. Linalool also possesses an anxiolytic effect [137], and this effect probably substantiates the folk uses of Skimmia anquetilia (Rutaceae) leaves as medicine for headache and freshness. Linalool is the main constituent of Skimmia root. The indigenous uses of six species Arisaema flavum, Ficus religiosa, Rhododendron campanulatum (Figure 2), Smilax aspera, Solena heterophylla and Sterculia villosa repudiated to any of the comparables, since these uses were additional to the Nepalese ethnomedicinal vault and these addition demands further research.

Aconitum spicatum (Ranunculaceae), taken alone is poisonous, so it is never used alone by the local communities. A paste made from its roots is applied as antipyretic and analgesic after mixing with Terminalia chebula (Combretaceae). Folk use of root extract of $A$. spicatum as an analgesic is consistent to the anti-inflammatory activity of caffeic acid found in the plant extract [138]. About $80 \%$ of plant alkaloids possesses antiinflammatory properties and among them isoquinoline (berbamine, berberine, cepharanthine and tetrandine) was the most active $[139,140])$. Diterpenoid alkaloids, commonly isolated from the plants of Ranunculaceae family, are commonly found to have antimicrobial properties [141]. Folk uses as antipyretic and analgesic of $A$. spicatum root extract are validated by the in vitro antimicrobial properties. In some cases, multi-component therapy has been practiced and considered as effective

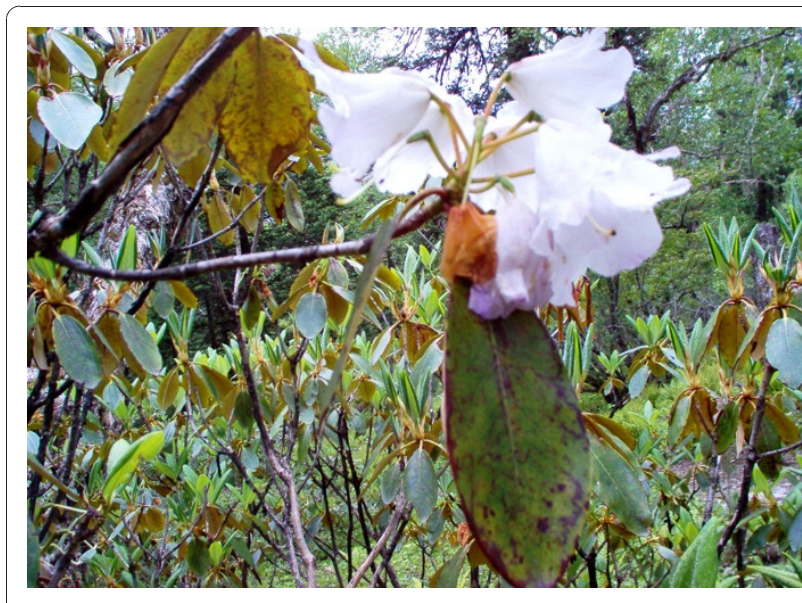

Figure 2 Rhododendron campanulatum D.Don (Chimal): Flowers are used in body ache and throat pain. 
as Kareru et al. [142] observed in Kenya, but the present assessment considered only the primary one to discuss. We believe that the associate plants must also be considered as excellent candidates for future studies to determine the mechanisms of their activity, as well as for the isolation and identification of active constituents $[143,144]$. Thus, traditional herbal medicine renders primary health care needs of two thirds of the rural population of the Nepalese, represents a largely unexplored source for potential development of new drugs $[145,146]$.

\section{Conclusions}

Validation of the ethnomedicinal uses of 48 Nepalese medicinal plants using comparative assessment with the common uses of the Ayurveda, earlier studies and the latest phytochemical findings showed that the folk uses of only about $50 \%, 70 \%$ and $40 \%$ of plant species respectively exhibited affinity. The folk uses of Acacia catechu for cold and cough, Aconitum spicatum as an analgesic, Aesculus indica for joint pain, Andrographis paniculata for fever, Anisomeles indica for urinary affections, Azadirachta indica for fever, Euphorbia hirta for asthma, Taxus wallichiana for tumor control, and Tinospora sinensis for diabetes are consistent with the latest pharmacological findings, as well as common Ayurvedic and earlier uses. However, the frequent folk uses of Arisaema flavum, Ficus religiosa, Rhododendron campanulatum, Smilax aspera, Solena heterophylla and Sterculia villosa of study area repudiated at all. The preliminary results obtained from the present assessment indicate that further investigation of ethnopharmacology is worthwhile. The validity assessment from the present research provided the potential to identify, research, and use which plants and their ingredients are the most significant for treatment of particular diseases.

\section{Acknowledgements}

The authors wish to thank the Canadian Center for International Studies and Co-operation (CECI), Kathmandu, International Center for Integrated Mountain Development (ICIMOD), Lalitpur, Water Resource Consult, Lalitpur, and Resource and Environmental Conservation Society, Kathmandu for providing facilities for field studies and data analysis. Thanks are also due to Laxmi Kunwar, Meera Pandey, CM Burlakoti, P Budha, and CL Chowdhary for their support.

\section{Author details \\ ${ }^{1}$ Ethnobotanical Society of Nepal, GPO Box 5220, Kathmandu, Nepal. ${ }^{2}$ Natural History Museum, Swayambhu, Tribhuvan University, Kathmandu, Nepal. ${ }^{3}$ William L. Brown Center, Missouri Botanical Garden, St. Louis, MO 63166- 0299, USA.}

\section{Authors' contributions}

All authors share the contributions to this manuscript. RMK carried out field research, analyzed the data, and wrote the manuscript, and KPS and RWB designed the study, supervised the work, collected the literature, and revised the manuscript. All authors approved the final version of this manuscript.

\section{Competing interests}

The authors declare that they have no competing interests.

Received: 21 June 2010 Accepted: 13 December 2010

Published: 13 December 2010

\section{References}

1. Farnsworth NR, Soejarto DD: Global importance of medicinal plants. In The conservation of medicinal plants. Edited by: Akerelev O, Heywood V, Synge H. Cambridge University Press, Cambridge; 1991:25-51.

2. Bhattarai NK: Traditional phytotherapy among the Sherpa of Helambu, Central Nepal. Journal of Ethnopharmacology 1989, 27(1/2):45-54.

3. Kamboj VP: Herbal medicine. Current Science 2000, 78(1):35-39.

4. Ghimire SK, McKey D, Aumeeruddy-Thomas Y: Conservation of Himalayan medicinal plants: harvesting patterns and ecology of two threatened species Nardostachys grandiflora and Neopicrorhiza scrophulariiflora. Biological Conservation 2005, 124:463-475.

5. Burlakoti C, Kunwar RM: Folk herbal medicines of Mahakali watershed Area, Nepal. In Medicinal Plants in Nepal: An Anthology of Contemporary Research. Edited by: Jha PK, Karmacharya SB, Chettri MK, Thapa CB, Shrestha BB. Ecological Society, Kathmandu, Nepal; 2008:187-193.

6. Bussmann RW: Ethnobotany and biodiversity conservation. In Modern Trends in Applied Terrestrial Ecology. Edited by: Ambasht RS, Ambasht NK. Kluwer publishers, Dordrecht, The Netherlands; 2002:345-362.

7. Patwardhan B, Warude D, Pushpangadan P, Bhatt N: Ayurveda and Traditional Chinese Medicine: A comparative overview. eCAM 2005, 2(4):465-473

8. Goswami S, Annalakshmi C, Panda N, Banerjee S, Sahu NP, Achari B, Das PK: Preclinical experimental evidence for anti gastric ulcer activity in an Indian medicinal plant. Abstract presented in the 2nd International Conference on Recent Advances in Biomedical and Therapeutic Sciences Bundelkhand University, India; 2005.

9. Khan S, Balick MJ: Therapeutic plants of the Ayurveda: a review of selected clinical and other studies for 166 species. Journal of Alternative and Complementary Medicine 2001, 7(5):405-515.

10. Kunwar RM, Nepal BK, Kshetri HB, Rai SK, Bussmann RW: Ethnomedicine in Himalaya: a case study from Dolpa, Humla, Jumla and Mustang districts of Nepal. Journal of Ethnobiology and Ethnomedicine 2006, 2-27[http:// www.ethnobiomed.com/content/2/1/27].

11. Bailey CJ, Day C: Traditional plant medicines as treatment for diabetes. Diabetes Care 1989, 12:553-564.

12. Keen RW, Deacon AC, Delves HT, Moreton JA, Frost PG: Indian herbal remedies for diabetes as a cause of lead poisoning. Postgraduate Medical Journal 1994, 70:113-114.

13. Taylor RSL, Edel F, Manandhar NP, Towers GHN: Antimicrobial activities of southern Nepalese medicinal plants. Journal of Ethnopharmacology 1996, 50:97-102.

14. Kunwar RM, Uprety $Y$, Burlakoti C, Chowdhary CL, Bussmann RW: Indigenous use and ethnopharmacology of medicinal plants in Far-west Nepal. Journal of Ethnobotany Research \& Applications 2009, 7:5-28.

15. Bhattarai NK: Medical ethnobotany in Karnali zone, Nepal. Economic Botany 1992, 46(3):257-261.

16. Kala CP: Current status of medicinal plants used by traditional Baidhyas in Uttaranchal, India. Journal of Ethnobotany Research \& Applications 2005, 3:267-278.

17. Kunwar RM, Bussmann RW: Medicinal, aromatic and dye plants of Baitadi and Darchula districts, Nepal Himalaya: status, uses and management. In Biodiversitat und Naturausstattung im Himalaya III. Edited by: Hartmann M, Weipert J. Naturekunde Museum, Erfurt, Germany; 2009:43-49.

18. Cunningham AB: Applied ethnobotany, people, wild plant use and conservation Earthscan publishing limited. London and Sterling VA; 2001, 300.

19. Stainton A, Polunin O: Flowers of the Himalaya Oxford University Press, New Delhi-India; 1984, 580.

20. Stainton A: Flowers of the Himalaya, a supplement Oxford University Press, New Delhi-India; 1988, 86.

21. Bajracharya MB: Ayurvedic medicinal plants and general treatment Piyusavarsi Ausadhalaya Mahaboudha, Kathmandu, Nepal; 1979, 230.

22. Dash B, Gupta K: Materia medica of Ayurveda based on Mandanapala's Nighantu B Jain Publishers, New Delhi, India; 1994, 780. 
23. Warrier PK, Nambiar VPK, Ramankutty C, (eds): Indian medicinal plants: A compendium of 500 species Orient Longman Publishers, Kottakkal, India; 1994, 1-5.

24. Dey AC: Indian medicinal plants used in Ayurvedic preparation Bishen Singh Mahendra Pal Singh, Dehra Dun, India; 1998.

25. Rajbhandari TK, Joshi NR, Shrestha T, Joshi SKG, Acharya B: Medicinal plants of Nepal for Ayurvedic Drugs Government of Nepal, Department of Plant Resources, Thapathali, Kathmandu; 1995, 387.

26. Sapkota CR, Adhikari SM: Ayurvedic pharmacology (Bheshaja Guna-Vijnana) Singhadurbar Vaidyakhana Vikas Samiti. Anamnagar, Kathmandu, Nepal; 2001

27. Joshi SG: Medicinal plants Oxford \& IBH Publishing. New Delhi, India; 2006, 491.

28. Rajbhandari KR: Ethnobotany of Nepal Ethnobotanical Society of Nepal, Kathmandu, Nepal; 2001, 189.

29. Lama YC, Ghimire SK, Thomas YA: Medicinal plants of Dolpo: Amchis' knowledge and conservation People and Plants program and WWF Nepal, Kathmandu; 2001, 150.

30. Manandhar NP: Plants and People of Nepal Timber Press, Portland, Oregon USA; 2002, 599.

31. IUCN Nepal: National Register of Medicinal and Aromatic Plants (Revised \& updated) The World Conservation Union, Nepal; 2004, 202.

32. Watanabe T, Rajbhandari KR, Malla KJ, Yahara S: A handbook of medicina plants of Nepal Ayur Seed Life Environmental Institute, Japan; 2005, 262.

33. Baral SR, Kurmi PP: A compendium of medicinal plants in Nepal Mrs Rachana Publishers, Kathmandu, Nepal; 2006, 534.

34. Manandhar NP: Native phytotherapy among the Raute tribe of Dadeldhura district, Far-west Nepal. Journal of Ethnopharmacology 1998, 60:199-206.

35. Kunwar RM, Bussmann RW: Ethnobotany in the Nepal Himalaya. Journal of Ethnobiology and Ethnomedicine 2008, 4:24[http://www.ethnobiomed.com/ content/4/1/24].

36. Dhar U, Manjkhola S, Joshi M, Bhatta A, Bisht AK, Joshi M: Current status and future strategy for development of medicinal plant sector in Uttranchal, India. Current Science 2002, 83(8):956-964.

37. Bhattarai NK: Folk medicinal uses of indigenous aromatic plants of Nepal. In Supplement to cultivation and utilization of aromatic plants. Edited by: Handa SS, Kaul MK. Council of Scientific and Industrial Research, India; 1997:469-483.

38. Bhattarai S, Chaudhary RP, Quave CL, Taylor RSL: The use of medicinal plants in the Trans-Himalayan arid zone of Mustang district, Nepal. Journal of Ethnobiology and Ethnomedicine 2010, 6:14

39. Kunwar RM, Acharya RP, Bussmann RW: Medicinal plants in Nepal Western Himalaya: status, trade, use and community management. Journal of Ethnobotany Research \& Applications 2010, 9

40. Shirwaikar A, Verma R, Lobo R, Shirwaikar A: Phytotherapy - safety aspects. Natural Product Radiance 2009, 8:55-63.

41. Gillam S: The traditional healer as village health worker. Journal of Institute of Medicine 1989, 11:67-76.

42. WRI: World Resources - 2005. The wealth of the poor: managing ecosystems to fight poverty. World Resource Institute, USA. 2005 [http:// www.wri.org/publication/world-resources-2005-wealth-poor-managingecosystems-fight-poverty].

43. Joshi KR: Ethnomedicinal uses of plants: a case study from Sharmoli VDC, Darchula district, Nepal. In Medicinal Plants in Nepal: An Anthology of Contemporary Research. Edited by: Jha PK, Karmacharya SB, Chettri MK, Thapa CB, Shrestha BB. Ecological Society, Kathmandu, Nepal; 2008:178-187.

44. Farnsworth NR, Morris RW: Higher plants - the sleeping giant of drug development. American Journal of Pharmaceutical Education 1976, 148:46-52.

45. Connolly DL: Chemistry of limonoids of the Meliaceae and Cneoraceae. In Chemistry and chemical taxonomy of the Rutales. Edited by: Waterman PG, Grundon MF. Academic Press, London; 1983.

46. Bhattarai S, Chaudhary RP, Taylor RSL: Ethnomedicinal plants used by the people of Nawalparasi district, Central Nepal. Our Nature 2009, 7:82-89.

47. Farnsworth NR: Biological and phytochemical screening of plants. Journal of Pharmaceutical Science 1966, 55:225.

48. Wall ME: Antimutagenic agents from natural products. Journal of Natural Products 1992, 55:1561-1568.

49. Khalid SA, Farouk A, Geary TG, Jensen JB: Potential antimalarial candidates from African plants: an in vitro approach using Plasmodium falciparum. Journal of Ethnopharmacology 1986, 15:201-209.
50. Phillipson JD, Wright CW: Can ethnopharmacology contribute to the development of antimalarial agents? Journal of Ethnopharmacology 1991, 32:155-165.

51. Krugliak M, Deharo E, Shalmiev G, Sauvain M, Moretti C: Antimalarial effects of c18 fatty acids on plasmodium. Experimental Parasitology 1995, 81:97-105

52. Madhav S, Tandan SK, Lal J: Anti-inflammatory activity of andrographolide. Fitoterapia 1996, 67:452-458.

53. Batkhuu J, Hattori K, Takano F, Fushiya S, Oshiman K, Fujimiya Y: Suppression of NO production in activated macrophages in vitro and ex vivo by Neoandrographolide isolated from Andrographis paniculata. Biological and Pharmaceutical Bulletin 2002, 25(9):1169-1174.

54. Hikino $\mathrm{H}$, Kiso $\mathrm{Y}$ : Natural products for liver diseases. In Economic and medicinal plant research. Volume 2. Academic Press, London; 1988:39-72.

55. Koul IB, Kapil A: Effect of diterpenes from Andrographis paniculata on antioxidant defense system and lipid peroxidation. Indian Journal of Pharmacology 1994, 26:296-300.

56. Sharma M, Tripathi P, Singh VP, Tripathi YS: Hepato-protective and toxicological evaluation of Hepatomed, an Ayurvedic drug. Indian Journal of Experimental Biology 1995, 33:34-37.

57. Evans WC: An overview of drugs having antihepatotoxic and oral hypoglycaemic activities. Trease and Evans' Phamacognosy. 14 edition. UK, WD Sanders Company Ltd; 1996.

58. Puri A, Saxena R, Saxena RP, Saxena KC: Immuno-stimulant agent from Andrographis paniculata. Journal of Natural Products 1993, 56:995.

59. Verma N, Vinayak M: Antioxidant action of Andrographis paniculata on lymphoma. Molecular and Biological Reproduction 2008, 35:535-540.

60. Chiou WF, Chen CF, Lin JJ: Mechanism of suppression of indictable nitric oxide synthase (iNOS) expression in RAW 264.7 cells by andrographolide. British Journal of Pharmacology 2000, 129:1553-1560

61. Gozalbes R, Gálvez J, García-Domenech R, Derouin F: Molecular search of new active drugs against Toxoplasma gondii. SAR QSAR Environmental Research 1999, 10:47-60.

62. Anderson LA, Phillipson JD: Mistletoe, the magic herb. Pharmacy Journal 1982, 229:437-439.

63. Singh J, Shah NC: Podophyllum: A Review. Current Research on Medicinal and Aromatic Plants 1994, 16:53-83.

64. Filho JMB, Piuvexam MR, Moural MD, Silval MO, Batista KV, Cunhal EVL, FEchine IM, Takemura OS: Anti-inflammatory activity of alkaloids: a twenty century review. Rev Bras Farmacogn 2006, 16(1), Jan./Mar.

65. Li WL, Zheng HC, Bukura J, Kimpe ND: Natural medicines used in traditional Chinese medicines for diabetes mellitus. Journal of Ethnopharmacology 2004, 92:1-21

66. Zhao T, Wang X, Rimando AM, Che C: Folkloric Medicinal Plants: Tinospora sagittata var. cravaniana and Mahonia bealei. Planta Medica 1991, 57:505-506.

67. Kar A, Choudhary BK, Bandyopadhyay NG: Comparative evaluation of hypoglycaemic activity of some Indian medicinal plants in alloxan diabetic rats. Journal of Ethnopharmacology 2003, 84:105-108.

68. Jagetia GC, Rao SK: Evaluation of the antineoplastic activity of Guduchi (Tinospora cordifolia) in Ehrlich Ascites carcinoma bearing mice. Biological and Pharmaceutical Bulletin 2006, 29:460-466.

69. Prince PSM, Menon PV, Gunasekharan G: Hypolipidaemic action of Tinospora cordifolia root in alloxane diabetic rats. Journal of Ethnopharmacology 1999, 64:53-57.

70. Marles RJ, Farnsworth NR: Anti-diabetic plants and their active constituents. Phytomedicine 1995, 2:137-189.

71. Mitich LW: Intriguing world of weeds. Tansy Weed Technology 1992, 6:242-244.

72. Berry MI: Feverfew faces the future. Pharmacy Journal 1984, 232:611.

73. Rizk AFM: The chemical constituents and economic plants of the Euphorbiaceae. In Euphorbiales: Chemistry, Taxonomy and Economic Botany. Edited by: Jury SL, Reynolds T, Cutler TDF, Evans FJ. Academic Press Inc. London; 1987:293-326.

74. Abubakar El-Mahmood M: Antibacterial activity of crude extracts of Euphorbia hirta against some bacteria associated with enteric infections. Journal of Medicinal Plant Research 2009, 3(7):498-505.

75. Vijaya K, Ananthan S, Nalini R: Antibacterial effect of theaflavin, polyphenon 60 (Camellia sinensis) and Euphorbia hirta on Shigella spp. a cell culture study. Journal of Ethnopharmacology 1995, 49:115-118. 
76. Adedapo AA, Shabi OO, Adedokun OA: Antihelminthic efficacy of the aqueous extract of Euphorbia hirta (Linn.) in Nigerian dogs. Vet Arch 2005, 75(1):39-47.

77. Falodun A, Okunrobe LO, Uzoamaka N: Phytochemical screening and antiinflammatory evaluation of methanolic and aqueous extracts of Euphorbia heterophylla. African Journal of Biotechnology 2006, 5(6):529-531.

78. Arora R, Basu N, Kapoor V: Anti-inflammatory studies on Curcuma longa (turmeric). Indian Journal of Medical Research 1971, 59:1289-1295.

79. Chandra D, Gupta S: Anti-inflammatory and anti-arthritic activity of volatile oil of Curcuma longa (Haldi). Indian Journal of Medical Research 1972, 60:138-142.

80. Kohli K, Ali J, Ansari MJ, Raheman Z: Curcumin: a natural antiinflammatory agent. Indian Journal of Pharmacology 2005, 37:141-147.

81. Negi PS, Jayaprakasha GK, Jagan Mohan Rao L, Sakariah KK: Antibacterial activity of turmeric oil: a byproduct from curcumin manufacture. Journal of Agriculture and Food Chemistry 1999, 47:4297-4300

82. Bourne KZ, Bourne N, Reising SF, Stanberry LR: Plant products as topical microbicide candidates: assessment of in vitro and in vivo activity against herpes simplex virus 2. Antiviral Research 1999, 42(3):219-226.

83. Apisariyakul A, Vanittanakom N, Buddhasukh D: Antifungal activity of turmeric oil extracted from Curcuma longa (Zingiberaceae). Journal of Ethnopharmacology 1995, 49:163-169.

84. Kuttan R, Sudheeran PC, Joseph CD: Turmeric and curcumin as topical agents in cancer therapy. Tumori 1987, 73:29-31.

85. Kawamori T, Lubet R, Steele VE: Chemopreventative effect of curcumin, a naturally occurring anti-inflammatory agent, during the promotion/ progression stages of colon cancer. Cancer Research 1999, 59:597-601.

86. Itthipanichpong C, Ruangrungsi N, Kemsri W, Sawasdipanich A: Antispasmodic effects of curcuminoids on isolated guinea-pig ileum and rat uterus. Journal of Medical Association of Thailand 2003, 86:299-309.

87. Park EJ, Jeon $\mathrm{CH}, \mathrm{Ko} \mathrm{G}$ : Protective effect of curcumin in rat liver injury induced by carbon tetrachloride. Journal of Pharmacy and Pharmacology 2000, 52:437-440.

88. Selvam R, Subramanian L: The anti-oxidant activity of turmeric (Curcuma longa). Journal of Ethnopharmacology 1995, 47:59-67.

89. Kunchandy E, Rao MNA: Oxygen radical scavenging activity of curcumin. International Journal of Pharmacy 1990, 58:237-240.

90. Sui Z, Salto R, Li J, Craik C, Ortiz de Montellano PR: Inhibition of the HIV-1 and HIV-2 proteases by curcumin and curcumin boron complexes. Bioorganic Medical Chemistry 1993, 1:415-422.

91. Mazumder A, Wang S, Neamati N, Nicklaus M, Sunder S, Chen J: Antiretroviral agents as inhibitors of both human immunodeficiency virus type 1integrase and protease. Journal of Medical Chemistry 1996, 39:2472-2481.

92. Kuttan R, Bhanumathy P, Nirmala K, George MC: Potential anti-cancer activity of turmeric (Curcuma longa). Cancer Letters 1985, 29:97-202.

93. Dikshit M, Rastogi L, Shukla R, Srimal RC: Prevention of ischaemia-induced biochemical changes by curcumin and quinidine in cat heart. Indian Journal of Medical Research 1995, 101:31-35.

94. Usher G: Acacia catechu Willd (Catechu, Dark catechu). A dictionary of plants. Delhi: CBS publishers and distributors, India; 11984

95. Rage N, Dahanukar S, Karandikar SM: Hepato-protective effect of cyanidanol against carbon tetrachloride induced liver damage. Indian Drugs 1984, 22:556-560.

96. Cowan MM: Plant products as antimicrobial agents. Clinical Microbiology Reviews 1999, 12:564-582[http://cmr.asm.org/cgi/content/full/12/4/564].

97. Cipak L, Grausova L, Miadokova E, Novotny L, Rauko P: Dual activity of triterpenoids. Archieves of Toxicology 2006, 80:429-435.

98. Rajnarayana K, Reddy MS, Chaluvadi MR, Krishna DR: Bi-flavonoids classification, pharmacological, biochemical effects and therapeutic potential. Indian Journal of Pharmacology 2001, 33:2-16.

99. Geetha BS, Mathew BC, Augusti KT: Hypoglycemic effects of Leucodelphinidin derivative isolated from Ficus bengalensis (Linn.). Indian Journal of Physiology and Pharmacology 1994, 38:220-222.

100. Rastogi RP, Mehrotra BN: In A compendium of medicinal plants. Volume 2. Central Drugs Research Institute, Lucknow and Publication and Information Directorate, New Delhi; 1979:833.

101. van Wyk BE, Wink M: Medicinal plants of the World Briza Publications, South Africa; 2004, 480

102. Cortes-Maramba NP, Dayrit FM, de Castro NF, Estrada HR, Lim-Sylianco CY, Lingao AL, Quijano RF, Quintana EG: Selection and scientific validation of medicinal plants for primary health care Philippine Council for Health Research and Development; 1991, 42-43, Technical Report Series No. 12.

103. Samy RP, Ignacimuthu S, Sen A: Screening of 34 Indian medicinal plants for antibacterial properties. Journal of Ethnopharmacology 1998, 62:173-182.

104. Kumar VP, Chauhan NS, Padh H, Rajani M: Search for antibacterial and antifungal agents from selected Indian medicinal plants. Journal of Ethnopharmacology 2006, 107:182-188.

105. Villasenor IM, Lamadrid MRA: Comparative anti-hyperglycemic potentials of medicinal plants. Journal of Ethnopharmacology 2006, 104:129-131.

106. Masilungan VA, Vadlamudi S, Goldin A: Screening of Philippine medicinal plants for anticancer agents using CCNSC protocols. Cancer Chemotherapy Reports 1971, 2:135-140.

107. Amann W: Acne vulgaris and Agnus castus. Z Allgemeinmed 1975, 51(35):1645-1648, (Published in German).

108. Telang RS, Chaterjee S, Varshneya C: Study on anagelsic and antiinflammatory activities of Vitex negundo. Genetic Pharmacology 1999, 31(5):363-366.

109. Singh AM, Malhotra S, Subban R: Anti-inflammatory and analgesic agents from Indian medicinal plants. International Journal of Integrative Biology 2008, 3(1):57-72

110. Nair AM, Saraf MN: Inhibition of antigen and compound $48 / 80$ induced contractions of guinea pig trachea by the ethanolic extract of the leaves of Vitex negundo Linn. Indian Journal of Pharmacology 1995, 27:230-233.

111. Bhattarai NK: Folk herbal medicines of Makwanpur District, Nepal. International Journal of Pharmacognosy 1991, 29(4):284-295.

112. Page D, Baniya CB, Taylor RSL: Isolation of biologically active compounds from ethnobotanically important Nepalese lichens. Ecoprint 2003, 10(1):1-6.

113. Huneck S: The significance of lichens and their metabolites. Naturwissenschaften 1999, 86:559-576.

114. Aslan A, Güllüce $M$, Atalan E: A study of antimicrobial activity of some lichens. Bulletin of Pure and Applied Science 2001, 20:23-26.

115. Karagoz A, Dougroz N, Zeybck Z, Aslan A: Antibacterial activity of some lichen extract. Journal of Medicinal Plants Research 2009, 3(12):1034-1039.

116. Cocchietto M, Skert N, Nimis PL: A review on usnic acid, an interesting natural compound. Naturwissenschaften 2002, 89:137-146.

117. Rankovic B, Misic M, Sukdolak S: Evaluation of antimicrobial activity of the lichens Lasallia pustulata, Parmelia sulcata, Umbilicaria crustulosa and Umbilicaria cylindrica. Mikrobiologya 2007, 76(6):817-821.

118. Momoh MA, Adikwu MU: Evaluation of the effect of colloidal silver on the antibacterial activity of ethanolic extract of the lichen Parmelia perlata. African Journal of Pharmacy and Pharmacology 2008, 2(6):106-109.

119. Malhotra S, Subban R, Singh A: Lichens-role in traditional medicine and drug discovery. The Internet Journal of Alternative Medicine 2008, 5(2).

120. Takahash RN, de Lima TC, Murato GS: Pharmacological actions of tannic acid; II. Evaluation of CNS activity in animals. Planta Medica 1986, $4: 272-275$

121. Mammela P, Savolainen $H$, Lindroos L, Kangas J, Vartiainen $T$ : Analysis of oak tannins by liquid chromatography-electrospray ionization mass spectrometry. Journal of Chromatography A 2000, 89:75-83.

122. Erdelyi K, Kiss A, Bakondi E, Bai P, Szabo C, Gergely P, Erdodi F, Virag L: Gallotannin inhibits the expression of chemokines and inflammatory cytokines in A549 cells. Molecular Pharmacology 2005, 68:895-904.

123. Marinova D, Ribarova F, Atanassova M: Total phenolics and total flavonoids in Bulgarian fruits and vegetables. Journal of University Chemistry, Technology and Metallurgy 2005, 40(3):255-260.

124. Chanwitheesuk A, Teerawutgulrag A, Rakariyatham N: Screening of antioxidant activity and antioxidant compounds of some edible plants of Thailand. Food Chemistry 2005, 92:491-497.

125. Lisiewska Z, Kmiecik W, Korus A: Content of vitamin C, carotenoids, chlorophylls and polyphenols in green parts of dill (Anethum graveolens L.) depending on plant height. Journal of Food Composition Annals 2006, 19(2-3):134-140.

126. Longo L, Vasapollo G: Extraction and identification of anthocyanins from Smilax aspera. Food Chemistry 2006, 94:226-231.

127. Harborne JB, Williams CA: Advances in flavonoids research since 1992. Phytochemistry 2000, 55:481-504.

128. Caragay AB: Cancer-preventative foods and ingredients. Food Technology 1992, 46:65-68. 
129. Willcox JK, Ash SL, Catignani GL: Antioxidants and prevention of chronic disease. Critical Review of Food Science and Nutrition 2004, 44:275-295.

130. Kumpulainen JT, Salonen JT: Natural Antioxidants and Anticarcinogens in Nutrition, Health and Disease The Royal Society of Chemistry, UK; 1999, 178-187.

131. van Wyk BE: Food plants of the World: identification, culinary uses and nutritional values Briza Publication, South Africa; 2005

132. Joshi AR, Joshi K: Indigenous knowledge and uses of medicinal plants by local communities of the Kali Gandaki watershed area, Nepal. Journal of Ethnopharmacology 2000, 73:175-183.

133. Kunwar RM, Duwadee NPS: Ethnobotanical notes on flora of Khaptad National Park, far-west Nepal. Himalayan Journal of Sciences 2003, 1:25-30.

134. Ma SC, Du J, But PP, Deng XL, Zhang YW, Ooi VE, Xu HX, Lee SH, Lee SF: Antiviral Chinese medicinal herbs against respiratory synctial virus. Journal of Ethnopharmacology 2002, 79:205-211.

135. Hui KM, Huen MS, Wang HY, Zheng H, Sigel E, Baur R, Ren H, Li ZW, Wong ZT, Xue H: Anxiolytic effect of Wogonin isolated from Scutellaria baicalensis. Biochemical Pharmacology 2002, 464:1-8.

136. CSIR: In The Wealth of India: Raw Materials. Volume 1-10. Council of Scientific and Industrial Research (CSIR), New Delhi, India; 1998.

137. Lopez R, Pina MB, Estrada RR, Heinze G, Martinez VM: Anxiolytic effect of hexane extract of the leaves of Annona cherimolia in two anxiety paradigms: possible involvement of the GABA/Benzodiazepine receptor complex. Life Science 2006, 78:730-737.

138. Park KH, Park M, Choi SE, Jeong MS, Kwon JH, Oh MH, Choi HK, Seo SJ, Lee MW: The antioxidative and anti-inflammatory effects of Caffeoyl derivatives from the roots of Aconitum koreanum. Biological and Pharmaceutical Bulletin 2009, 32(12):2029-2033.

139. Wong CW, Seow WK, Ocallaghan JW, Thong YH: Comparative effects of tetrandrine and berbamine on subcutaneous air pouch inflammation induced by interleukin 1, tumour necrosis factor and platelet-activating factor. Agents Actions 1992, 36:112-118.

140. Ono M: Inflammation Inhibitors Containing Cepharanoline or Berbamine Patent-Japan Kokai Tokkyo Koho-06 211; 1994, 661

141. Omulokoli E, Khan B, Chhabra SC: Antiplasmodial activity of four Kenyan medicinal plants. Journal of Ethnopharmacology 1997, 56:133-137.

142. Kareru PG, Kenji GM, Gachanja AN, Keriko JM, Mungai G: Traditional medicines among the Embu and Mbeere peoples of Kenya. African Journal of Traditional Complementary and Alternative Medicine 2007, 4:75-86.

143. Kunwar RM, Burlakoti CM, Chowdhary CL, Bussmann RW: Medicinal plants in far-west Nepal: Indigenous uses and pharmacological validity. Medicinal and Aromatic Plant Science and Technology 4 (Special issue 1) Global Science Books, UK; 2010

144. Rokaya MB, Munzbergova Z, Timsina B: Ethnobotanical study of medicinal plants from the Humla district of western Nepal. Journal of Ethnopharmacology 2010, 130:485-504.

145. Kunwar RM, Bussmann RW: Medicinal plants and quantitative ethnomedicine: a case study from Baitadi and Darchula districts, farwest Nepal. Journal of Natural History Museum 2009, 24:73-82.

146. Uprety Y, Asselin H, Boon EK, Yadav S, Shrestha KK: Indigenous use and bioefficacy of medicinal plants in the Rasuwa district, Central Nepal. Journal of Ethnobiology and Ethnomedicine 2010, 6:3[http://www. ethnobiomed.com/content/6/1/3]

147. Ambasta SP, Ramchandran K, Kashyapa K, Chand R: The useful plants of India Council of Science and Industrial Research (CSIR), New Delhi; 1992.

148. Terada T, Fujimoto K, Nomura M, Yamashita J, Kobunai T, Takeda S, Wierzba K, Yamada Y, Yamaguchi H: Antitumor agents. I. DNA topoisomerase II inhibitory activity and the structural relationship of podophyllotoxin derivatives as antitumor agents. Chemical and Pharmaceutical Bulletin 1992, 40:2720-2727.

149. Goel HC, Prasad J, Sharma A, Singh B: Antitumour and radio-protective action of Podophyllum hexandrum. Indian Journal of Experimental Biology 1998, 36:583-587.

150. Nazir T, Uniyal AK, Todaria NP: Allelopathic behavior of three medicinal plant species on traditional agriculture crops of Garhwal Himalaya, India. Agroforestry System 2006, 69(3):183-187.

151. Kirtikar KR, Basu BD: In Indian medicinal plants. Volume II. International Book Distributors, India; 1981:838

152. Kirtikar KP, Basu BD: In Indian medicinal plants. Volume 1. Bishen Singh Mahendra Pal Singh, Dehra Dun, India; 1935
153. Bhattacharjee SK: Handbook of medicinal plants. 5 edition. Pointer publishers, Jaipur, India; 2008, 494

154. Aitzetmüller K: Antioxidative effects of Carum seeds. JAOCS 1997, $74(2): 185$.

155. lacobellis NS, Lo CP, Capasso F, Senatore F: Antibacterial activity of Cuminum cyminum L. and Carum carvi L. essential oils. Journal of Agriculture and Food Chemistry 2005, 53:57-61.

156. Muthaiyan K, Kumaraswami D, Murugan S, Namasivayam N: Effect of dietary caraway (Carum carvi L.) on aberrant crypt foci development, fecal steroids, and intestinal alkaline phosphatase activities in 1,2dimethylhydrazine-induced colon carcinogenesis. Toxicology and Applied Pharmacology 2006, 214:290-296.

157. Koelz WN: Notes on ethnobotany of Lahul, Punjab. Quarterly Journal of Crude Drug Research 1979, 17(1):1-56.

158. Eddouks M, Lemhadri A, Michel JB: Caraway and caper: potential antihyperglycemic plants in diabetic rats. Journal of Ethnopharmacology 2004, 94:143-148.

159. Mc Laughlin JL, Miller RW, Powell RG, Smith CR: Hydroxy baccatin, deacetylcephalomannine and deacetyltaxol: new antitumor taxanes from Taxus wallichiana. Journal of Natural Products 1981, 44(3):312-318.

160. Deshpande VH, Patil AD: Flavonoids of Acacia catechu heartwood. Indian Journal of Chemistry 1981, 20:628.

161. Singh KN, Mittal RK, Barthwal KC: Hypoglycemic activity of Acacia catechu, Acacia suma, Albizzia odoratissima seed diets in normal albino rats. Indian Journal of Medical Research 1976, 64:754-757.

162. Ray DK, Thokchom IS: Antipyretic, antidiarrhoeal, hypoglycaemic and hepato-protective activities of ethyl acetate extract of Acacia catechu in albino rats. Indian Journal of Pharmacology 2006, 38:408-413.

163. Jayasekhar P, Mohanan PV, Rathinam K: Hepato-protective activity of ethyl acetate extract of Acacia catechu. Indian Journal of Pharmacology 1997 29:426-428.

164. Wang YH, Wang WY, Chang CC, Liou KT, Sung YJ, Liao JF, Chen CF Chang S, Hou YC, Chou YC, Shen YC: Taxifolin ameliorates cerebral ischemia-reperfusion injury in rats through its anti-oxidative effect and modulation of NF-kappa B activation. Journal of Biomedical Science 2006 13(1):127-141.

165. Wallis TE: Cutch: text book of pharmacognosy. 5 edition. London: J \& A Churchill Ltd; 1967.

166. Chapagain DJ, Joshi SD, Jnawali SR: Indigenous use of medicinal plants by the Tharu community in the southern buffer zone of Bardia National Park, Nepal. Proceeding of IV National Conference on Science and Technology 2004, 738-751

167. Lin WY, Peng CF, Tsai IL, Chen JJ, Cheng MJ, Chen IS: Antitubercular constituents from the roots of Engelhardtia roxburghiana. Planta Medica 2005, 71(2):171-175.

168. Arif M, Zaman K, Fareed S, Hussain MS: Antibactetial, antidiarrhoeal and ulcer protective activity of methanolic extract of Spondias mangifera bark. International Journal of Health Research 2008, 1(4):172-182.

169. Tannert U: Shellac, a natural polymer for hair care products. Cosmetics Conference. Frankfurt, 4-6th March, Germany 1992

170. Rastogi RP, Mehrotra BN: In A compendium of medicinal plants. Volume 1. Central Drugs Research Institute, Lucknow and Publication and Information Directorate, New Delhi; 1969:497.

171. Prakash D, Upadhyay G, Singh BN, Dhakarey R, Kumar S, Singh KK: Free Radical Scavenging activities of Himalayan Rhododendrons. Current Science 2007, 92(4):526-532.

172. Young HS, Lee CK, Park SW, Park KY, Kim KW, Chung HY, Yokozawa T, Oura $\mathrm{H}$ : Anti-tumorigenic effects of ursolic acid isolated from the leaves of Eriobotrya japonica. Natural Medicine 1995, 49:190-192.

173. Kim KW: Anticancer activities of plant triterpenoids, ursolic acid and oleanoid acid. J Korean Assoc Cancer Prevention 1997, 2:38-44.

174. Jain SK, Sinha BK, Gupta RC: Notable plants in ethnomedicine of India Deep Publications, New Delhi, India 1991, 219.

175. Nair CKN, Mohanan N: Medicinal plants of India with species reference to Ayurveda NAG Publishers. Delhi, India; 1998, 501.

176. Choudhary BR, Poddar MK: Andrographolide and kalmeg extracts; effects on intestinal brush border-membrane bound hydrolases methods. Findings of Experimental Clinical Pharmacology 1985, 7:617. 
177. Rana AC, Avadhoot Y: Hepato-protective effects of Andrographis paniculata against carbon tetrachloride induced liver damage. Archieves of Pharmacy Research 1991, 14(1):93-95

178. Visen PK, Shukla B, Patnaik GK, Dhawan BN: Andrographolide protects rat hepatocytes against paracetamol-induced damage. Journal of Ethnopharmacology 1993, 40(2):131-136

179. Devkota HP, Basnet P, Yahara S: Diterpenes esters and phenolic compounds from Sapium insigne. Chemical and Pharmaceutical Bulletin 2009, 57(11):1289-1291.

180. Park IW, Hang C, Song X, Green LA, Wang T, Liu Y, Chen C, Yang B, Chen G, He JJ: Inhibition of HIV I entry by extract derived from traditional chinense medicinal herb plants. BMC Complementary and Alternative Medicine 2009, 9:29[http://www.biomedcentral.com].

181. Husain A, Virmani OP, Popali SP, Mishra LN, Gupta MM, Srivastava GN Abraham Z, Singh AK: Dictionary of Indian medicinal plants Central Institute of Medicinal and Aromatic Plants (CIMAP). Lucknow, India; 1992

182. Garcia-Argaez AN, Ramirez-Apan TO, Delgado HP, Velazquez G, MartinezVasquez M: Anti-inflammatory activity of coumarins from Decatropis bicolor on TPA ear mice model. Planta Medica 2000, 66:279-281.

183. Foster S, Duke JA: A field guide to medicinal plants Eastern and Central N. America. Houghton Mifflin Co; 1990, ISBN. 0395467225.

184. Moermann D: Native American ethnobotany Timber Press, Portland, Oregon, USA; 1998, 453-459.

185. Parekh J, Chanda S: Antibacterial and phytochemical studies on twelve species of Indian medicinal Plants. African Journal of Biomedical Research 2006, 10:175-181.

186. Rajkapoor B, Jayakar B, Murugesh N: Antitumor activity of Bauhinia variegata on Dalton's ascitic lymphoma. Journal of Ethnopharmacology 2003, 89:107-109.

187. Vinutha B, Prasanth D, Salma K, Sreeja SL, Pratiti D, Padmaja R, Radhika S, Amit A, Ventakeshwarlu K, Deepak M: Screening of selected Indian medicinal plants for acetylcholinesterase inhibitory activity. Journal of Ethnopharmacology 2007, 109:359-363.

188. Sreelekshmi R, Latha PG, Arafat MM, Shyamal S, Shine VJ, Anuja GI, Suja SR, Rajasekharan S: Antiinflammatory, analgesic and antilipid peroxidation studies on the stem bark of Ficus religiosa. Natural Product Radiance 2007, 6(5):377-381

189. Agarwal V, Chauhan BM: A study of composition and hypolipidemic effect of dietary fibre from some plant foods. Plant Foods and Human Nutrition 1988, 38(2):189-197.

190. Mangrio SM, Dahot MU, Leghari SM: Chemical constituents of Equisetum debile. Pakistan Journal of Plant Science 1995, 1(1):41-48.

191. Pourmorad F, Hosseinimehr SJ, Shahabimajd N: Antioxidant activity, phenol and flavonoids contents of some selected Iranian medicinal plants. African Journal of Biotechnology 2006, 5(11):1142-1145.

192. KC SK, Muller K: Medicinal plants from Nepal: evaluation as inhibitors of lipid peroxidation in biological membranes. Journal of Ethnopharmacology 1999, 64:135-139.

193. KC SK, Zieries K, Wiegrebe W, Muller K: Medicinal plants from Nepal. Evaluation as inhibitors of leukotriene bio-synthesis. Journal of Ethnopharmacology 2000, 70:191-195.

194. Rajbhandari M, Mentel R, Jha PK, Chaudhary RP, Bhattarai S, Gewali MB, Karmacharya N, Hipper M, Lindequest U: Antiviral activity of some plants used in Nepalese traditional medicine. eCAM 2007, 6(4):517-522

195. Siddiqui BS, Faizi S, Siddiqui G, Siddiqui S: Chemistry of Neem (Azadirachta indica), a sustainable source of natural pesticide. Neem and Environment Oxford \& IBH Publishing, New Delhi; 1993

196. Khanna N, Goswami M, Sen P, Ray A: Antinociceptive action of Azadirachta indica (neem) in mice: possible mechanisms involved. Indian Journal of Experimental Biology 1995, 33:848-850.

197. CCRAS: In Pharmacological investigation of certain medicinal plants and compound formulations used in Ayurveda and Siddha. Edited by: Pandey VN, Malhotra SC, Sharma DP. Central Council for Research in Ayurveda 1996.

198. Fabry W, Okema PO, Ansorg R: Antibacterial activity of east African medicinal plants. Journal of Ethnopharmacology 1998, 60:79-84

199. Tahir AE, GMH Satti, Khalid SA: Antiplasmodial activity of selected Sudanese medicinal plants with emphasis on Maytenus senegalensis. Journal of Ethnopharmacology 1999, 64:227-233.

200. Dorababu M, Joshi MC, Bhawani G, Kumar MM, Chaturvedi A, Goel RK Effect of aqueous extract of neem (Azadirachta indica) leaves on offensive and defensive gastric mucosal factors in rats. Indian Journal of Physiology and Pharmacology 2006, 50:241-249.

201. Halim EM: Lowering of blood sugar by water extract of Azadirachta indica and Abroma augusta in diabetic rats. Indian Journal of Experimental Biology 2003, 41(6):636-640

202. Rao YK, Fang SH, Hsieh SC, Yeh TH, Tzeng YM: The constituents of Anisomeles indica and their anti-inflammatory activities. Journal of Ethnopharmacology 2009, 121(2):292-296.

203. Dharmasiri MG, Ratnasooriya WD, Thabrew MI: Water extract of leaves and stems of pre-flowering but not flowering plants of Anisomeles indica possesses analgesic and antihyperalgesic activities in Rats. Pharmaceutical Biology 2003, 41(1):37-44.

204. Wang YC, Huang TL: Screening of anti-Helicobacter pylori herbs deriving from Taiwanese folk medicinal plants. FEMS Immunology \& Medical Microbiology 2005, 43(2):295-300.

205. Shahidul AM, Quader MA, Rashid MA: HIV-inhibitory diterpenoid from Anisomeles indica. Fitoterapia 2000, 71:574-576.

206. Rizzini CT: The uses of lichens in medicine. Bras Med 1952, 66(3839):589-596.

207. Singh RK, Nath G, Goel RK, Bhattacharya SK: Pharmacological actions of Abies pindrow Royle leaf. Indian Journal of Experimental Biology 1988, 36:187-191.

208. Brown JP: A review of the genetic effects of naturally occurring flavonoids, anthroquinones and related compounds. Mutation Research 1980, 75:243-277.

209. Oliveira FA, Vieira-Junior GM, Chaves MH, Almeida FR, Florencio MG, Lima RC, Silva RM, Santos FA, Rao VS: Gastroprotective and antiinflammatory effects of resin from Protium heptaphyllum in mice and rats. Pharmacological Research 2004, 49:105-111.

210. Rastogi RP, Mehrotra BN: A compendium of Indian medicinal plants CDRI Lucknow and Publications \& Information Directorate, New Delhi; 1993.

211. Iman RA, Priya BL, Chithra R, Shalini K, Sharon V, Chamundeeswari D, Vasantha J: In vitro antiplatelet activity-guided fractionation of aerial parts of Melothria maderaspatana. Indian Journal of Pharmacological Science 2006, 68:668-670

212. Wu HC, Si HC, Fan NC, Ho JA: Antioxidant activity and melanogenesis inhibitory effect of the acetonic extract of Osmanthes fragrans: a potential natural and functional food flavor additive. Food Science and Technology 2009, 42(9):1513-1529.

213. Wang H, Gan D, Zhang X, Pan Y: Antioxidant capacity of the extracts from pulp of Osmanthes fragrans and its components. Food Science and Technology 2010, 43(2):319-325

214. Lee HH, Lin CT, Ling YL: Neuroprotection and free radical scavenging effects of Osmanthes fragrans. Journal of Biomedical Science 2007, 14(6):819-827.

215. Madhuri S, Pandey G: Some anticancer medicinal plants of foreign origin. Current Science 2009, 96(6):779-783.

216. Azuine MA, Kayal JJ, Bhide SV: Protective role of aqueous turmeric extract against mutagenicity of direct-acting carcinogens as well as benzo(a) pyrene-induced genotoxicity and carcinogenicity. Journal of Cancer Research and Clinical Oncology 1992, 118:447-452.

217. Mali RG, Mehta AA: A review on anthelmintic plants. Natural Product Radiance 2008, 7(5):466-475.

218. Achliya GS, Wadodkar SG, Dorle AK: Evaluation of CNS activity of Brahmi Ghrita. Indian Journal of Pharmacology 2005, 37:33-36.

219. Dash GK, Bijayini M, Panda A, Patro CP, Ganapaty S: Anthelmintic activity of Evolvulus numullarius. Indian Journal of Natural Products 2003, 19:24-26.

220. Saini V, Kinger HK, Sharma DK, Ahuja N, Middha A, Gupta VB: Wound healing activities of Evolvulus nummullarius. Asian Journal of Chemistry 2007, 19:5772-5774.

221. Pavithra PS, Srividya N, Verma RS: Antibacterial and antioxidant activity of methanol extract of Evolvulus nummullarius. Indian Journal of Pharmacology 2009, 41:233-236.

222. Bradley PR: In British Herbal Compendium. Volume 1. BHMA; 1992, ISBN No. 0-903032-09-0.

223. Otsuka H, Fujioka S, Komiya T, Goto M, Hiramatsu Y, Fujimura H: Studies on anti-inflammatory agents; a new anti-inflammatory constituents of Pyracantha crenulata. Chemical and Pharmaceutical Bulletin 1981, 29(11):3099-3104. 
224. Wang KH, Lin RD, Hsu FL, Huang YH, Chang HC, Huang CY, Lee MH: Cosmetic applications of selected traditional Chinese herbal medicines. Journal of Ethnopharmacology 2006, 106:353-359.

225. WHO: WHO Regional publication western pacific series No.21. Medicinal Plants in the Republic of Korea WHO Regional office Manila; 1998, 316

226. Shao F, Hu Z, Xiong YM, Huang QZ, Wang CG, Zhu RH, Wang DC: A new antifungal peptide from the seeds of Phytolacca americana: characterization, amino acid sequence and cDNA cloning. Biochem Biophys Acta 1999, 1430:262-268.

227. Uckan FM, Rustamova L, Vassilev AO, Tibbles HE, Petkevich AS: CNS activity of pokeweed anti-viral protein (PAP) in mice infected with lymphocytic choriomeningitis virus (LCMV). BMC Infectious Diseases 2005, 5:9.

228. Buckingham J: In Dictionary of Natural Products. Volume 7. Chapman and Hall 2-6 Boundary Row, London, UK; 1994

229. Oran SA, Al-Eiwasi DM: Checklist of medicinal Plants in Jordan. Dirasat. Medical and Biological Sciences 1998, 25:84-112.

230. Chen PN, Chu SC, Chiou HL, Kuo WH, Chiang CL, Hsieh YS: Mulberry anthocyanins, cyanidin-3-rutinoside and cyanidin-3-glucoside, exhibited an inhibitory effect on the migration and invasion of a human lung cancer cell line. Cancer Letters 2006, 235:248-259.

231. Okoli CO, Akals PA, Nwafor SV: Anti-inflammatory activities of Plants. Journal of Natural Remedies 2003, 3(1):1-30.

232. Burkill HM: In The useful plants of west tropical African families MFT. Volume 4. Royal Botanic Garden, Kew; 1994:605.

233. Justicia adhatoda [http://en.wikipedia.org/wiki/Justicia_adhatoda].

234. Luheshi GN: Cytokine and fever. Mechanism and sites of action. Annals of New York Academy of Science 1998, 856:83-89.

235. Rege NN, Javle H, Bapat RD: Antiendotoxic effect of Tinospora cordifolia: an experimental study in rats. Indian Journal of Surgery 1998, 60:303-305.

236. Dahanukar SA, Thatte UM: Current status of Ayurveda in phytomedicine. Phytomedicine 1997, 4:359-368.

237. Mukherjee PK, Saha K, Das J, Pal M, Saha BP: Studies on the antiinflammatory activity of rhizomes of Nelumbo nucifera. Planta Medica 1997, 63:367-369.

238. Chakraborthy GS: Evaluation of immunomodulatory activity of Aesculus indica. International Pharmaceutical Technical Research 2009, 1(2):132-134.

239. Prajapati ND, SS Purohit, AK Sharma, Kumar T: A handbook of medicinal plants: a complement source book Agrobios India (reprint); 2006, 554

240. Go N: Bulletin of Department of Medicinal Plants No. 28. Medicinal Plants of Nepal Ministry of Forest and Soil Conservation, Thapathali Kathmandu, Nepal; 2007, 402

doi:10.1186/1746-4269-6-35

Cite this article as: Kunwar et al:: Traditional herbal medicine in Farwest Nepal: a pharmacological appraisal. Journal of Ethnobiology and Ethnomedicine 2010 6:35.

\section{Submit your next manuscript to BioMed Central and take full advantage of:}

- Convenient online submission

- Thorough peer review

- No space constraints or color figure charges

- Immediate publication on acceptance

- Inclusion in PubMed, CAS, Scopus and Google Scholar

- Research which is freely available for redistribution 